\title{
OS CAMINHOS DE UM NOVO PARADIGMA DO PLANEAMENTO URBANÍSTICO EM PORTUGAL ${ }^{1}$
}

\author{
THE PATHS FOR A NEW URBAN PLANNING CONCEPT IN PORTUGAL
}

\author{
Fernando Alves Correia*
}

\begin{abstract}
Resumo:
$\mathrm{O}$ presente artigo pretende sublinhar a fundamentalidade do planeamento urbanístico no moderno direito do urbanismo. Todavia, para que o planeamento e o plano continuem a desempenhar essa função essencial, devem os mesmos interiorizar novas preocupações e novas exigências. Podemos falar, à luz da nova legislação e dos mais recentes contributos doutrinários, de um "novo paradigma do planeamento urbanístico português". Como manifestações mais relevantes, podem citar-se, para além do planeamento urbanístico coordenado e multinível, o planeamento impulsionador do desenvolvimento urbano sustentável, o planeamento urbanístico socialmente sustentável, o planeamento de contenção urbanística, o planeamento urbanístico que toma em consideração a mobilidade urbana, o planeamento urbanístico aberto à participação dos cidadãos, à concertação e à contratualização, o planeamento urbanístico estimulador da reabilitação urbana, o planeamento urbanístico fomentador da segurança urbana, o planeamento urbanístico incentivador da proteção e valorização do património cultural e o planeamento urbanístico promotor da observância do princípio constitucional da igualdade. $\mathrm{O}$ artigo encerra com a interrogação sobre os impactos da pandemia da doença da COVID-19 no direito do urbanismo do futuro.
\end{abstract}

Palavras-chave: Planeamento urbanístico. Plano. Desenvolvimento urbano sustentável. Contenção urbanística. Mobilidade urbana suave. Reabilitação urbana. Segurança urbana. Património cultural. Participação, concertação e contratualização. Princípio da igualdade. COVID-19.

\begin{abstract}
:
This paper intends to underline the fundamentality of urban planning in modern urban planning law. However, for planning continue to fulfill this essential function, it must internalize new concerns and new demands. Considering the new legislation and the most recent doctrinal contributions, we can speak of a "new paradigm of portuguese urban planning". The most relevant manifestations include, in addition to coordinated and multilevel urban planning, sustainable urban development, socially sustainable urban planning, urban containment planning, urban planning that takes urban mobility into account, urban planning open to citizen participation, consultation and contracting, urban planning that encourages urban renewal,
\end{abstract}

1 O presente texto corresponde, nas suas linhas essenciais, à comunicação oral apresentada no dia 4 de setembro de 2019, na Faculdade de Direito da Universidade de São Paulo, no âmbito das 1ªs Jornadas LusoBrasileiras de Direito do Urbanismo, tendo sido revisto e atualizado à data de 31 de julho de 2020.

* Professor Catedrático da Faculdade de Direito da Universidade de Coimbra e Presidente do Conselho Diretivo do Centro de Estudos de Direito do Ordenamento, do Urbanismo e do Ambiente (CEDOUA). 
urban planning that promotes urban security, urban planning that encourages the protection and enhancement of cultural heritage and urban planning that promotes the observance of constitutional principle of equality. The study is concluded with a question about the impacts of the COVID-19 pandemic disease on the urbanism of the future.

Keywords: Urban planning. Plan. Sustainable urban development. Urban containment. Smooth urban mobility. Urban renewal. Urban security. Cultural heritage. Participation, consultation and contracting. Principle of equality. COVID-19.

\section{Introdução}

O planeamento e o plano são institutos fundamentais do direito do urbanismo, peças essenciais do ordenamento jurídico urbanístico, bases necessárias e imprescindíveis do regime jurídico urbanístico e eixos em torno dos quais gira a disciplina do urbanismo.

Todavia, os termos planeamento e plano não têm significados idênticos. $\mathrm{Na}$ verdade, planeamento é uma atividade que tem como fim a emanação de um plano, ao passo que este é o produto ou o objeto específico da referida atividade. O vocábulo planeamento expressa, assim, uma ideia de ação, de procedimento, enquanto o plano é algo que concretiza, que espelha o resultado do procedimento de planeamento.

À luz desta distinção, é concebível a existência de planeamento sem plano (bastando para tal que a atividade de planeamento não desemboque na aprovação de um plano), bem como a continuação do planeamento, após a aprovação do plano (o que atesta a negação do caráter rígido e imutável do plano). Para expressar esta última ideia, é utilizada a expressão "planeamento contínuo" com o significado de que a atividade de planeamento é perspetivada como um procedimento complexo, que compreende não só a elaboração e aprovação do plano, mas também a sua dinâmica e, ainda, a gestão, procedimento esse que, por sua vez, é concebido como um procedimento contínuo, que exige um eficiente sistema de acompanhamento e monitorização.

A fundamentalidade ou a essencialidade do planeamento e do plano deriva do facto de os mesmos constituírem um procedimento e um resultado de uma justa ponderação da multiplicidade de interesses coenvolvidos na utilização desse bem essencial e escasso, que é o solo (ponderação que reveste uma tríplice vertente: entre interesses

públicos e privados colidentes, entre interesses públicos que não são coincidentes e entre interesses privados divergentes).

A conceção do planeamento e do plano como institutos fundamentais do direito do urbanismo português resulta claramente, desde logo, da Constituição da República Portuguesa (CRP), cujo artigo $65^{\circ}$, n. $^{\circ} 4$, determina que 
o Estado, as regiões autónomas e as autarquias locais definem as regras de ocupação, uso e transformação dos solos urbanos, designadamente através de instrumentos de planeamento, no quadro das leis respeitantes ao ordenamento do território e ao urbanismo, e procedem às expropriações dos solos que se revelem necessárias à satisfação de fins de utilidade pública urbanística.

A importância primordial do planeamento e do plano no direito e política do urbanismo ressalta também do artigo $8 .^{\circ}$ da nova Lei de Bases Gerais da Política Pública de Solos, de Ordenamento do Território e de Urbanismo (LBPSOTU), aprovada pela Lei n. ${ }^{\circ} 31 / 2014$, de 30 de maio, e alterada pela Lei n. ${ }^{\circ} 74 / 2017$, de 16 de agosto, cujo n. ${ }^{\circ} 1$ prescreve que "o Estado, as regiões autónomas e as autarquias locais têm o dever de promover a política pública de solos, de ordenamento do território e de urbanismo, no âmbito das respetivas atribuições e competências, previstas na Constituição e na lei", tendo, para esse efeito, segundo a alínea $a$ ) do n. $^{\circ} 2$ do mesmo artigo, o dever, entre outros, de "planear e programar o uso do solo e promover a respetiva concretização".

Não é nosso objetivo, nesta breve comunicação, indicar os traços gerais do regime jurídico do planeamento urbanístico português, mas tão-só analisar, com base nos últimos desenvolvimentos legislativos ocorridos em Portugal, designadamente na mencionada LBPSOTU e no novo Regime Jurídico dos Instrumentos de Gestão Territorial (RJIGT), aprovado pelo Decreto-Lei n. ${ }^{\circ} 80 / 2015$, de 14 de maio, e nos mais recentes contributos doutrinários, as manifestações do "novo paradigma do planeamento urbanístico português".

II. Principais manifestações do novo paradigma do planeamento urbanístico português

1. Um planeamento urbanístico coordenado e multinível

A nova LBPSOTU e o novo RJIGT trouxeram modificações de relevo na estrutura do sistema de gestão territorial, ou, numa formulação mais rigorosa, na estrutura do sistema de programação e de planeamento territorial. O mesmo organiza-se num quadro de interação coordenada, que se reconduz aos âmbitos nacional, regional, intermunicipal e municipal, em função da natureza e da incidência territorial dos interesses públicos prosseguidos, revestindo, por isso, uma índole multinível, no quadro do pluralismo de entes públicos territoriais portugueses.

E materializa-se em programas, que estabelecem o quadro estratégico de desenvolvimento territorial e as suas diretrizes programáticas ou definem a incidência espacial de políticas nacionais a considerar em cada nível de planeamento, sendo, por isso, instrumentos de orientação, que se limitam, em regra, a fixar opções gerais no que respeita à organização do território por eles abrangido e a estabelecer diretivas quanto 
ao ordenamento do espaço, a desenvolver e a densificar em planos, não tendo, por isso, idoneidade para definir as modalidades e intensidades de uso, ocupação e transformação do solo, e em planos, que condensam opções e ações concretas em matéria de planeamento e organização do território e definem o uso do solo, assumindo, assim, a natureza de instrumentos de afetação do espaço, ao mesmo tempo que servem de parâmetro de validade dos atos administrativos de gestão urbanística [artigos $38 .^{\circ}, \mathrm{n}^{\circ}{ }^{\mathrm{os}} 1$, alíneas $a$ ) e $b$ ), e 2, da LBPSOTU e $1 .^{\circ}$ a $3 .^{\circ}$ do RJIGT].

Esta distinção entre programas e planos percorre transversalmente todo o sistema de gestão territorial gizado pela nova Lei de Bases e pelo novo RJIGT. Os primeiros vinculam apenas as entidades públicas (quer a entidade pública que os aprovou, quer os restantes entes públicos), enquanto os segundos vinculam, para além das entidades públicas, ainda, direta e imediatamente, os particulares, isto é, têm eficácia plurisubjetiva (artigos 46. ${ }^{\circ}$, n. ${ }^{\text {os }} 1$ e 2, da LBPSOTU e 3. ${ }^{\circ}$ do RJIGT). Somente os planos territoriais vinculam direta e imediatamente os particulares. Daí que as normas dos programas territoriais necessitem para vincular os particulares da intermediação das normas dos planos territoriais. Isto mesmo resulta do $n .^{\circ} 5$ do artigo $3 .^{\circ}$ do RJGT, nos termos do qual "as normas dos programas territoriais que, em função da sua incidência territorial urbanística, condicionem a ocupação, uso e transformação do solo são obrigatoriamente integradas nos planos territoriais". ${ }^{2}$ Por tudo isto, apenas os planos territoriais podem ser catalogados como "planos urbanísticos".

\footnotetext{
Um outro princípio estritamente relacionado com o referido no texto é o de que o plano diretor municipal (ou intermunicipal, caso exista e o substitua) deve concentrar ou ser a sintese de todas as regras definidoras do regime de ocupação, uso e transformação do solo por eles abrangido.

Se este princípio da concentração no plano diretor municipal de todas as regras respeitantes à ocupação, uso e transformação do solo já existia na legislação anterior, em decorrência dos princípios da legalidade e da hierarquia dos planos e, bem assim, do princípio de que o plano diretor municipal devia acolher todas as servidões e restrições de utilidade pública que estabelecessem condicionantes ao seu conteúdo, o mesmo ganhou uma ênfase particular na nova legislação, em face, sobretudo, do desaparecimento da eficácia plurisubjetiva dos planos especiais. São manifestações impressivas daquele princípio da concentração os artigos $46 .^{\circ}$, n. ${ }^{\circ} 4$ a 6 , e $78 .^{\circ}$ da LBPSOTU, bem como os artigos $28 .^{\circ}, 29 .^{\circ}$ e $198 .^{\circ}$ do RJGT.

Assim, o artigo $46 .^{\circ}$, n. $^{\circ} 4$, do primeiro diploma legal prescreve que "os programas territoriais que prossigam objetivos de interesse nacional ou regional, cujo conteúdo em função da sua incidência territorial urbanística deva ser vertido em plano diretor intermunicipal ou municipal e em outros planos territoriais, estabelecem, ouvidos a associação de municípios ou os municípios abrangidos, o prazo para a atualização destes planos e indicam expressamente as normas a alterar, nos termos da lei". O n. ${ }^{\circ} 5$ do mesmo preceito estatui que, findo um tal prazo, se a associação de municípios ou o município não tiver procedido à referida atualização, suspendem-se as normas do plano territorial intermunicipal ou municipal que deveriam ter sido alteradas, não podendo, na área abrangida, haver lugar à prática de quaisquer atos ou operações que impliquem a alteração do uso do solo, enquanto durar a suspensão. E o n..$^{\circ} 6$ do mesmo artigo vai mais longe ainda, prescrevendo que, sem prejuízo de outras sanções previstas na lei, a falta de iniciativa, por parte de associação de municípios ou município, tendente a desencadear o procedimento de atualização do plano intermunicipal ou municipal, bem como o atraso da mesma atualização por facto imputável às referidas entidades, implica a rejeição de candidaturas de projetos a benefícios ou subsídios outorgados por entidades
} 
Quanto aos programas, podem ser de âmbito nacional, regional e intermunicipal (artigos $40 .^{\circ}$ a $42 .^{\circ}$ da LBPSOTU e $30 .^{\circ}$ a $68 .^{\circ}$ do RJIGT). Os primeiros abrangem o programa nacional da política de ordenamento do território, os programas sectoriais e os programas especiais (que compreendem os programas da orla costeira, os programas das áreas protegidas, os programas de albufeiras de águas públicas, os programas de ordenamento dos estuários e, ainda, os "planos de ordenamento dos parques arqueológicos", previstos na Lei n. ${ }^{\circ}$ 107/2001, de 8 de setembro, e no Decreto-Lei n. ${ }^{\circ}$ 131/2002, de 11 de maio). Os segundos, isto é, os programas de âmbito regional, são os agora denominados programas regionais, que substituem os atuais planos regionais de ordenamento do território, os quais continuam em vigor até à sua alteração ou revisão, como decorre do artigo $79 .^{\circ}$ da LBPSOTU. Os terceiros, ou seja, os programas de âmbito intermunicipal, são de elaboração facultativa e abrangem ou a área geográfica correspondente à totalidade de uma entidade intermunicipal (área metropolitana ou comunidade intermunicipal) ou a área geográfica de dois ou mais municípios territorialmente contíguos integrados na mesma comunidade intermunicipal, salvo

ou serviços públicos nacionais ou comunitários, bem como a não celebração de contratos-programa, até à regularização da situação.

Por seu lado, o artigo 78..$^{\circ}$ da LBPSOTU - o qual foi alterado pela Lei n. ${ }^{\circ} 74 / 2017$, de 16 de agosto determina, no seu n. ${ }^{\circ} 1$, que o conteúdo dos planos especiais de ordenamento do território em vigor deve ser transposto, nos termos da lei, para o plano diretor intermunicipal ou municipal e outros planos intermunicipais ou municipais aplicáveis à área abrangida pelos planos especiais, até 13 de julho de 2020 (prazo este que terá passado para 14 de janeiro de 2021, por efeito do artigo $35 .^{\circ}-\mathrm{D}, \mathrm{n} .^{\circ} 1$, do Decreto-Lei n. ${ }^{\circ}$ 20/2020, de 1 de maio, o qual determinou que o prazo previsto no . $^{\circ} 1$ do artigo $78 .^{\circ}$ da Lei n. ${ }^{\circ}$ 31/2014, de 30 de maio, para transposição do conteúdo dos planos especiais de ordenamento do território para os planos diretores intermunicipais ou municipais e outros planos intermunicipais ou municipais aplicáveis à área abrangida pelos planos especiais fica suspenso até 180 dias após a cessação do estado de emergência, imposto por causa da pandemia da doença da COVID-19).

$\mathrm{O} n .^{\circ} 2$ do mesmo artigo preceitua que "compete às comissões de coordenação e desenvolvimento regional, com o apoio das entidades responsáveis pela elaboração dos planos especiais de ordenamento do território em vigor e das associações de municípios e municípios abrangidos por aqueles, a identificação, no prazo de um ano a contar da data da entrada em vigor da presente lei, das normas relativas aos regimes de salvaguarda de recursos territoriais e valores naturais diretamente vinculativas dos particulares que devam ser integradas em plano intermunicipal ou municipal". O n. 3 do artigo $78 .^{\circ}$ prescreve que as normas identificadas pelas comissões de coordenação e desenvolvimento regional nos termos do número anterior são comunicadas à associação de municípios ou município em causa, para efeitos de atualização dos planos intermunicipais e municipais, sendo aplicável o disposto no n. ${ }^{\circ} 4$ do artigo $46 .^{\circ}$ da LBPSOTU. O n. ${ }^{\circ} 4$ do artigo $78 .^{\circ}$ estabelece que, findo o prazo de três anos, os planos especiais continuam a vigorar, mas deixam de vincular direta e imediatamente os particulares, sem prejuízo do disposto nos n. ${ }^{\text {os }} 5$ e 6 do artigo $46 .^{\circ}$ da LBPSOTU. O n. ${ }^{\circ} 5$ dispõe que "aos planos especiais são aplicáveis, com as devidas adaptações e enquanto estes ainda vigorarem, as disposições relativas à alteração, suspensão e medidas preventivas aplicáveis aos planos intermunicipais e municipais". E o n. ${ }^{\circ} 6$ do mesmo artigo preceitua que, "sem prejuízo do disposto no número anterior, a alteração de planos especiais vigentes não pode ter lugar depois do procedimento de transposição determinado nos números anteriores, nem determinar uma dificuldade acrescida para a respetiva integração nos planos intermunicipais e municipais".

As mencionadas disposições do RJIGT vão em sentido bastante próximo, pelo que se dispensa a sua transcrição. 
situações excecionais, autorizadas pelo membro do Governo responsável pela área do ordenamento do território, após parecer das comissões de coordenação e desenvolvimento regional [artigos $42 .^{\circ}$, n. $^{\circ} 1$, da LBPSOTU e $61 .^{\circ}$, n. $^{\circ} 2$, alíneas $a$ ) e b), do RJIGT].

Quer isto dizer que os programas intermunicipais ou abrangem todos os municípios integrados na mesma entidade intermunicipal, havendo, assim, um novo nível de ordenamento do espaço correspondente ao território dos municípios que fazem parte da mesma entidade intermunicipal, e cabendo aos respetivos órgãos representativos a competência para a sua aprovação [o conselho metropolitano, nas áreas metropolitanas, e a assembleia intermunicipal, nas comunidades intermunicipais, como resulta do artigo $68 .^{\circ}$, n. $^{\circ} 1$, alínea $a$ ), do RJIGT] ou abrangem dois ou mais municípios territorialmente contíguos integrados na mesma entidade intermunicipal, podendo haver, neste caso, a constituição de uma associação de municípios para o fim específico da elaboração e aprovação do programa intermunicipal [a aprovação tem lugar por deliberação das assembleias municipais interessadas, mediante proposta apresentada pelas respetivas câmaras municipais, como flui do artigo $68 .^{\circ}$, n. $^{\circ}$ 1, alínea $b$ ), do RJIGT]. De qualquer modo, a nova LBPSOTU e o novo RJIGT vieram reforçar o associativismo municipal no âmbito do ordenamento e do planeamento do espaço, não só através da previsão dos programas intermunicipais, como também dos planos territoriais de âmbito intermunicipal, que englobam os planos diretores intermunicipais (que assumem a designação de "planos metropolitanos de ordenamento do território", quando abrangerem todos os municípios que integram uma área metropolitana), os planos de urbanização intermunicipais e os planos de pormenor intermunicipais (artigos $42 .^{\circ}$, n. $^{\circ} 4$, da LBPSOTU e $110 .^{\circ}$ a $114 .^{\circ}$ do RJIGT).

No que respeita aos planos territoriais de âmbito intermunicipal, há que realçar três notas: a primeira é que a aprovação de um plano diretor intermunicipal dispensa a elaboração de planos diretores municipais e substitui-os (artigos $42 .^{\circ},{ }^{\circ} .^{\circ}$, in fine, da LBPSOTU e $113 .{ }^{\circ},{ }^{\circ}{ }^{\circ}$, do RJIGT); a segunda consiste em que a existência de um plano diretor, de um plano de urbanização ou de um plano de pormenor de âmbito intermunicipal exclui a possibilidade de existência, ao nível municipal, de planos territoriais do mesmo tipo, na área por eles abrangida, sem prejuízo das regras relativas à dinâmica de planos territoriais (artigo $44 .{ }^{\circ}$, n. $^{\circ}$ 5, da LBPSOTU); e a terceira traduz-se em que a existência de um plano intermunicipal não prejudica o direito de cada município gerir autonomamente o seu território de acordo com o previsto nesse plano (artigo 42. ${ }^{\circ},{ }^{\circ}{ }^{\circ} 7$, da mesma lei).

Quanto aos planos territoriais de âmbito municipal, estabelecem, nos termos da Constituição da República Portuguesa (CRP) e da lei, de acordo com as diretrizes estratégicas de âmbito regional, e com opções próprias de desenvolvimento estratégico local, o regime de uso do solo e a respetiva execução e continuam a abarcar os planos diretores municipais, os planos de urbanização e os planos de pormenor (artigo 
$43 .^{\circ}$, n..$^{\text {s }} 1$ e 2 , da LBPSOTU e $69 .^{\circ}$ do RJIGT). O plano diretor municipal é de elaboração obrigatória, salvo se houver um plano diretor intermunicipal, e estabelece, nomeadamente, a estratégia de desenvolvimento territorial municipal, o modelo territorial municipal, as opções de localização e de gestão de equipamentos de utilização coletiva e as relações de interdependência com os municípios vizinhos (artigos $43 .^{\circ}$, n. $^{\circ} 3$, da LBPSOTU e 95..$^{\circ}$ do RJIGT). Por seu lado, o plano de urbanização desenvolve e concretiza o plano diretor municipal e estrutura a ocupação do solo e o seu aproveitamento, definindo a localização das infraestruturas e dos equipamentos coletivos principais (artigos $43 .^{\circ}, \mathrm{n} .^{\circ}$ 4, da LBPSOTU e $98 .^{\circ}$ do RJIGT). E o plano de pormenor desenvolve e concretiza o plano diretor municipal, definindo a localização e a volumetria das edificações, a forma e organização dos espaços de utilização coletiva e o traçado das infraestruturas (artigos 43. n. ${ }^{\circ}$, da LBPSOTU e $101 .{ }^{\circ}$ do RJIGT).$^{3}$

\section{Um planeamento impulsionador do desenvolvimento urbano sustentável}

O conceito de desenvolvimento urbano sustentável, de sustentabilidade urbana ou de cidade sustentável é, atualmente, um conceito-chave no domínio do direito do urbanismo, como vem sendo sublinhado por vários documentos jurídicos nacionais, europeus e internacionais. A génese do mesmo está associada às múltiplas influências da proteção do ambiente no âmbito do direito do urbanismo e surge associado às noções de ambiente urbano e ecologia urbana. Mas a sua relevância transcende muito as imbricações do ambiente no urbanismo, bem espelhadas no artigo $66^{\circ}, \mathrm{n}^{\circ}{ }^{\circ}$, alínea $e$ ), da CRP, que constitucionaliza o conceito de "direito do ambiente urbano", através da utilização de um "direito do urbanismo ecológico" e de um "direito do ambiente urbano", com a finalidade precípua de promoção da "qualidade ambiental das povoações e da vida urbana", ${ }^{4}$ constituindo, hoje, o principal fim da política pública urbanística. $\mathrm{O}$ artigo $2 .^{\circ}$, alínea b), da LBPSOTU coloca a garantia do desenvolvimento sustentável com um dos fins cimeiros da política pública de solos, de ordenamento do território e de urbanismo.

A sustentabilidade urbana abrange cinco dimensões: a ambiental, a económica, a social, a cultural e a territorial. ${ }^{5}$ A mais relevante, para o ponto que ora

\footnotetext{
3 Para mais desenvolvimentos sobre o sistema de planeamento urbanístico português, Alves Correia, F. (2008, p. 346-602, 2014a, p. 9-21, 2018b, p. 521-538, 2018a, p. 9-25).

4 Alves Correia, F. (2008, p. 105-114, 2010, p. 220-228).

5 Sendo o "território" (no qual se deve incluir o espaço marítimo, numa lógica de salvaguarda da interação terra-mar) o "terminal necessário de grande parte da atividade humana" ou o fator de localização da maioria esmagadora das realizações humanas, pode dizer-se que é nele que se manifestam as preocupações de "desenvolvimento sustentável", nas suas dimensões ambiental, económico-financeira, social e cultural. (ALVES CORREIA, F., 2015, p. 235-240).
} 
nos preocupa, é a dimensão ambiental. E é nesse contexto que falamos em planeamento urbanístico do desenvolvimento urbano sustentável.

São várias as manifestações do desenvolvimento urbano sustentável no planeamento urbanístico.

2.1. A primeira expressão de influência do princípio do desenvolvimento sustentável na programação e no planeamento territorial é a da avaliação ambiental estratégica de planos e programas, a qual foi estabelecida pela Diretiva n. ${ }^{\circ}$ 2001/42/CE, do Parlamento e do Conselho, de 27 de junho, e transposta para o direito interno português pelo Decreto-Lei n. ${ }^{\circ}$ 232/2007, de 15 de junho, alterado pelo Decreto-Lei n. ${ }^{\circ}$ 58/2011, de 4 de maio. A avaliação ambiental de planos e programas foi consagrada no Direito da União Europeia para colmatar as insuficiências da Avaliação de Impacte Ambiental (AIA) de projetos. ${ }^{6}$ Aquela tem uma função diferente da AIA de projetos, dado que tem uma função estratégica, de análise de grandes opções, ao passo que esta tem uma função de avaliação do impacte ambiental dos projetos, tal como são executados em concreto.

A Diretiva n. ${ }^{\circ}$ 2001/42/CE e o Decreto-Lei n. ${ }^{\circ}$ 232/2007 contêm o regime material da avaliação ambiental dos instrumentos de planeamento territorial, mas é o RJIGT que encerra a disciplina procedimental da avaliação ambiental dos planos territoriais que a ela estão sujeitos, nos termos daquela diretiva e daquele decreto-lei.

No que concerne aos planos municipais de ordenamento do território e o mesmo se passa com os planos intermunicipais, no caso de existirem -, $a$ solução acerca da sua sujeição a avaliação ambiental não é idêntica para todos eles. Enquanto os planos diretores municipais estão sempre sujeitos a avaliação ambiental, uma vez que o artigo 97. ${ }^{\circ}$, n. $^{\circ}$ 2, alínea $b$ ), do RJIGT impõe que sejam acompanhados de um relatório ambiental, no qual se identificam, descrevem e avaliam os eventuais efeitos significativos no ambiente resultantes da aplicação do plano e as suas alternativas razoáveis, tendo em conta os objetivos e o âmbito de aplicação territorial respetivos, os planos de urbanização e os planos de pormenor nem sempre são objeto de avaliação ambiental. Com efeito, nos termos do artigo $78 .^{\circ}$, n. ${ }^{\circ}$ 1, do RJIGT, os planos de urbanização e os planos de pormenor só são objeto de avaliação ambiental no caso de se determinar que são suscetíveis de ter efeitos significativos no ambiente ou nos casos em que constituam o enquadramento para a aprovação de projetos sujeitos a avaliação de impacte ambiental ou a avaliação de incidências ambientais. A qualificação dos planos de urbanização e dos planos de pormenor sujeitos a avaliação ambiental compete à câmara municipal, de acordo com os critérios estabelecidos no anexo ao Decreto-Lei n. ${ }^{\circ}$ 232/2007, alterado pelo Decreto-

6 Aprovado pelo Decreto-Lei n. ${ }^{\circ}$ 151-B/2013, de 31 de outubro, alterado pelos Decretos-Leis n. ${ }^{\text {os }} 47 / 2014$, de 24 de março, e 179/2015, de 27 de agosto, pela Lei n. ${ }^{\circ}$ 37/2017, de 2 de junho, e pelo Decreto-Lei n. ${ }^{\circ}$ 152-B/2017, de 11 de dezembro. 
Lei n. ${ }^{\circ}$ 58/2011, podendo ser precedida de consulta às entidades às quais, em virtude das suas responsabilidades ambientais específicas, possam interessar os efeitos ambientais resultantes da aplicação do plano (artigo $78 .^{\circ}$, n. $^{\circ} 2$, do RJIGT). Acresce que, nos termos do n. 3 do artigo $78 .^{\circ}$ do RJIGT, tendo sido deliberada a elaboração de plano de urbanização ou de plano de pormenor, a câmara municipal solicita parecer sobre o âmbito da avaliação ambiental e sobre o alcance da informação a incluir no relatório ambiental, nos termos do artigo 5. ${ }^{\circ}$ do Decreto-Lei n. ${ }^{\circ}$ 232/2007, alterado pelo Decreto-Lei n. ${ }^{\circ}$ 58/2011.

Finalmente, na linha da delimitação conceptual das figuras da revisão e da alteração dos instrumentos de gestão territorial, estabelece o artigo $120 .^{\circ}$, n. $^{\circ} 1$, do RJIGT que as pequenas alterações aos programas e planos territoriais só são objeto de avaliação ambiental no caso de se determinar que são suscetíveis de ter efeitos significativos no ambiente. A qualificação das pequenas alterações aos instrumentos de gestão territorial suscetíveis de ter efeitos significativos no ambiente e consequente sujeição a avaliação ambiental compete à entidade responsável pela elaboração do plano ou do programa, de acordo com os critérios estabelecidos no anexo ao Decreto-Lei n. ${ }^{\circ} 232 / 2007$, alterado pelo Decreto-Lei n. ${ }^{\circ} 58 / 2011$, podendo ser precedida de consulta às entidades às quais, em virtude das suas responsabilidades ambientais específicas, possam interessar os efeitos ambientais resultantes da aplicação do plano (artigo $1200^{\circ}$, n. $^{\circ}$ 2, do RJIGT).

No que respeita aos procedimentos de avaliação ambiental dos instrumentos de gestão territorial, que, nos termos da Diretiva n. ${ }^{\circ}$ 2001/42/CE e do Decreto-Lei n. ${ }^{\circ}$ 232/2007, a ela estão sujeitos, o RJIGT incorporou "nos procedimentos de elaboração, acompanhamento, participação pública e aprovação dos instrumentos de gestão territorial a análise sistemática dos efeitos ambientais". Deixando de lado os programas territoriais e circunscrevendo-nos aos planos territoriais, podemos dizer que essa incorporação ocorreu por diferentes vias: a inclusão no conteúdo documental dos planos territoriais sujeitos a avaliação ambiental de um relatório ambiental, no qual se identificam, descrevem e avaliam os eventuais efeitos significativos no ambiente resultantes da aplicação do plano e as suas alternativas razoáveis, tendo em conta os objetivos e o âmbito de aplicação territorial respetivos [artigo $97 .^{\circ}, \mathrm{n}^{\circ}$, alínea $b$ ), relativamente aos planos diretores municipais; artigo $100 .^{\circ}$, n. $^{\circ}$, alínea $b$ ), no que concerne aos planos de urbanização; e artigo $107 .^{\circ}$, n. $^{\circ}$ 2, alínea $b$ ), no que respeita aos planos de pormenor]; a integração na comissão consultiva de elaboração dos planos das entidades às quais, em virtude das suas responsabilidades ambientais específicas, possam interessar os efeitos ambientais resultantes da aplicação do plano (artigos 83. ${ }^{\circ}$, n. ${ }^{\circ} 3$, e $86 .^{\circ}$ do RJIGT); a inclusão do relatório ambiental na concertação entre entidades públicas (artigo 87. ${ }^{\circ}$ do RJGT); a incidência da informação e participação do público sobre o relatório ambiental, bem como a submissão do mesmo a discussão pública, juntamente com a proposta do plano (artigos $88 .^{\circ}$ e $89 .^{\circ}$ do RJIGT); a ponderação do relatório ambiental, bem como a 
ponderação (e divulgação) dos resultados da discussão pública na elaboração da versão final da proposta do plano (artigo 89. ${ }^{\circ}$, n. ${ }^{\circ}$ 6, do RJIGT); o envio pela entidade competente pela elaboração do instrumento de gestão territorial sujeito a avaliação ambiental à Agência Portuguesa do Ambiente, ${ }^{7}$ após a sua publicação no Diário da República, da declaração ambiental, contendo os elementos acima referidos, a qual é disponibilizada ao público pela entidade responsável pela elaboração do plano através da respetiva página da Internet, podendo a mesma ser igualmente publicitada na página da Internet da Agência Portuguesa do Ambiente (artigo 190. ${ }^{\circ}$ do RJIGT); e a inserção da avaliação e controlo dos efeitos significativos da execução dos planos territoriais no ambiente no sistema geral da permanente avaliação da adequação e concretização da disciplina consagrada nos mesmos (artigo 187. ${ }^{\circ}$ do RJIGT).

2.2. A segunda manifestação de influência do princípio do desenvolvimento sustentável no planeamento territorial é o combate à poluição urbana e o fomento de espaços naturais na cidade, designadamente espaços verdes urbanos. Preocupações estas já presentes no "Livro Verde sobre o Ambiente Urbano da CEE", de 1990, e que foram desenvolvidas em Relatórios e Estratégias Temáticas posteriores da União Europeia (UE), tais como "European Sustainable Cities (1996)", "Promoting Sustainable Urban Development in Europe (2009)", "World and European Sustainable Cities Report (2010)", "Quality of Life in European Cities (2013 e 2016)" e "State of European Cities (2007, 2010 e 2016)", os quais constituem o que podemos designar como "acervo urbano da UE".

Nesta linha e relativamente a Portugal, é importante referir a Estratégia “Cidades Sustentáveis 2020", aprovada pela Resolução do Conselho de Ministros n. 61/2015, de 11 de agosto, a qual ambiciona responder às debilidades e necessidades de estruturação urbana do território e atuar no sentido de fortalecer e consolidar a visão de desenvolvimento territorial partilhada entre os agentes do território, contribuindo para a promoção das condições necessárias à competitividade, sustentabilidade e coesão nacional. A mesma procura promover cidades mais prósperas, mais resilientes, mais saudáveis, mais justas, mais inclusivas e mais conectadas. No campo específico das cidades mais saudáveis, pretende-se "cidades mais favoráveis ao fomento de padrões de vida saudável, que oferecem um ambiente urbano e espaços públicos de qualidade, e se ajustam às necessidades dos diferentes grupos populacionais, tirando partido dos recursos locais e promovendo lógicas de proximidade. Cidades que assumem o seu papel central no compromisso nacional com o paradigma emergente de ecoeficiência e de redução da sua

A orgânica da Agência Portuguesa do Ambiente, I. P., foi aprovada pelo Decreto-Lei n. ${ }^{\circ}$ 56/2012, de 12 de março, alterado pelo Decreto-Lei n. ${ }^{\circ}$ 55/2016, de 26 de agosto, e pelo Decreto-Lei n. ${ }^{\circ}$ 108/2018, de 3 de dezembro. 
pegada ecológica e carbónica, e a liderança nos processos de diminuição e qualificação do consumo e da redução do desperdício".

Importa sublinhar que tais finalidades estão em consonância com a Agenda 2030 de Desenvolvimento Sustentável e os seus 17 objetivos no quadro das Nações Unidas: erradicar a pobreza, erradicar a fome, saúde de qualidade, educação de qualidade, igualdade de género, água potável e saneamento, energias renováveis e acessíveis, trabalho digno e crescimento económico, indústria, inovação e infraestruturas, reduzir as desigualdades, cidades e comunidades sustentáveis, produção e consumo sustentáveis, ação climática, proteger a vida marítima, proteger a vida terrestre, paz, justiça e instituições eficazes e parcerias para a implementação dos objetivos.

São os planos municipais ou intermunicipais que definem os parâmetros para dimensionamento das áreas destinadas à implantação de espaços verdes e de utilização coletiva, infraestruturas viárias e equipamentos a incluir nos projetos de loteamento (artigo 43. ${ }^{\circ}$ do Regime Jurídico da Urbanização e Edificação - RJUE ${ }^{8}$ ) e que reservam os solos para infraestruturas urbanísticas, equipamentos e espaços verdes e outros espaços de utilização coletiva que sejam objeto de propriedade privada (artigos $18 .^{\circ}$ da LBPSOTU e $154 .^{\circ}$ do RJIGT). E são também eles que, ao estabelecerem a classificação e qualificação do solo, ao definirem o zonamento e ao determinarem as regras de ocupação, transformação e utilização do solo, isto é, ao delinearem as políticas urbanas, desempenham um papel determinante na luta contra a poluição urbana e no fomento da qualidade de vida urbana. Basta pensar no papel desempenhado pelos planos municipais no afastamento das zonas industriais dos aglomerados urbanos, de acordo com o princípio da separação territorial dos usos urbanística e ambientalmente incompatíveis, na localização das vias estruturantes de circulação automóvel fora dos centros urbanos, na vedação da circulação automóvel em certas artérias da cidade e no estímulo à utilização de meios não poluentes de mobilidade urbana.

2.3. Uma terceira expressão de influxo do princípio do desenvolvimento sustentável no planeamento territorial é a redução da poluição sonora.

$\mathrm{O}$ artigo 4. ${ }^{\circ}$ do Regulamento Geral do Ruído (RGR) ${ }^{9}$ consagra os princípios fundamentais sobre esta matéria, estabelecendo que compete ao Estado, às Regiões Autónomas, às autarquias locais e às demais entidades públicas, no quadro das suas

\footnotetext{
8 Aprovado pelo Decreto-Lei n. ${ }^{\circ}$ 555/1999, de 16 de dezembro, alterado e republicado pelo Decreto-Lei n. ${ }^{\circ}$ 136/2014, de 9 de setembro, retificado pela Declaração de Retificação n. ${ }^{\circ}$ 46-A/2014, de 10 de novembro, e alterado pelo artigo $7 .^{\circ}$ do Decreto-Lei n. ${ }^{\circ} 214-G / 2015$, de 2 de outubro, pelo Decreto-Lei n. ${ }^{\circ}$ 97/2017, de 10 de agosto, pela Lei n. ${ }^{\circ} 79 / 2017$, de 18 de agosto, pelo Decreto-Lei n. ${ }^{\circ} 121 / 2018$, de 28 de dezembro, pelo Decreto-Lei n. ${ }^{\circ}$ 66/2019, de 21 de maio, e pela Lei n. ${ }^{\circ} 118 / 2019$, de 17 de setembro.

9 Aprovado pelo Decreto-Lei n. ${ }^{\circ}$ 9/2007, de 17 de janeiro, alterado pelo Decreto-Lei n. ${ }^{\circ}$ 278/2007, de 1 de agosto.
} 
atribuições e das competências dos respetivos órgãos, promover as medidas de carácter administrativo e técnico adequadas à prevenção e controlo da poluição sonora, nos limites da lei e no respeito do interesse público e dos direitos dos cidadãos (n. ${ }^{\circ}$ ); que o Estado deve definir uma estratégia nacional de redução da poluição sonora e definir um modelo de integração da política de controlo de ruído nas políticas de desenvolvimento económico e social e nas demais políticas sectoriais com incidência ambiental, no ordenamento do território e na saúde (n. ${ }^{\circ}$ ); e que o Estado e as demais entidades públicas, em especial as autarquias locais, têm a responsabilidade de tomar todas as medidas adequadas para o controlo e minimização dos incómodos causados pelo ruído resultante de quaisquer atividades, incluindo as que ocorram sob a sua responsabilidade ou orientação (n. ${ }^{\circ} 3$ ).

Por seu lado, os artigos $6 .^{\circ}$ a $10 .^{\circ}$ do RGR registam as obrigações dos municípios em matéria de controlo e redução da poluição sonora e o papel do planeamento municipal na consecução deste objetivo. Assim, quanto a este último aspeto, o artigo $6 .^{\circ}$ determina que os planos municipais de ordenamento do território asseguram a qualidade do ambiente sonoro, promovendo a distribuição adequada dos usos do território, tendo em consideração as fontes de ruído existentes e previstas e impõe a obrigação de os municípios estabelecerem nos planos municipais de ordenamento do território a classificação, a delimitação e a disciplina das zonas sensíveis e das zonas mistas ${ }^{10}$ - classificação esta que é realizada na elaboração de novos planos e implica a revisão ou alteração dos planos municipais de ordenamento do território em vigor. Ademais, os municípios devem acautelar, no âmbito das suas atribuições de ordenamento do território, a ocupação dos solos com usos suscetíveis de vir a determinar a classificação da área como zona sensível, verificada a proximidade de infraestruturas de transporte existentes ou programadas.

Com o mesmo objetivo de controlo e redução da poluição sonora, o artigo $7 .^{\circ}$ do RGR obriga as câmaras municipais a elaborar mapas de ruído para apoiar a elaboração, alteração e revisão dos planos diretores municipais e dos planos de urbanização, de acordo com as indicações técnicas definidas naquele diploma legal. Obrigação essa sediada também nos artigos $97 .^{\circ}$, n. $^{\circ} 3$, alínea $d$ ), e $100 .^{\circ}$, n. $^{\circ} 3$, alínea e), do RJIGT, relativos ao conteúdo documental dos planos diretores municipais e dos planos de urbanização. E na mesma linha, o artigo 8. ${ }^{\circ}$ do RGR impõe aos municípios a obrigação de elaboração de planos municipais de redução do ruído destinados à diminuição da exposição a ruído

\footnotetext{
10 "Zona sensível" é a área definida em plano municipal de ordenamento do território como vocacionada para uso habitacional, ou para escolas, hospitais ou similares, ou espaços de lazer, existentes ou previstos, podendo conter pequenas unidades de comércio e de serviços destinadas a servir a população local, tais como cafés e outros estabelecimentos de restauração, papelarias e outros estabelecimentos de comércio tradicional, sem funcionamento no período noturno. Por seu lado, "zona mista" é a área definida em plano municipal de ordenamento do território, cuja ocupação seja afeta a outros usos, existentes ou previstos, para além dos referidos na definição de zona sensível [artigo 3. ${ }^{\circ}$, alíneas u) e v), do RGR].
} 
ambiente exterior de zonas sensíveis ou mistas que ultrapassem certos limites - planos cujo conteúdo é definido no artigo $9 .^{\circ}$ do mesmo diploma. E, finalmente, o artigo $10 .^{\circ}$ do mesmo diploma dita que as câmaras municipais apresentam à assembleia municipal, de dois em dois anos, um relatório sobre o estado do ambiente acústico municipal, exceto quando esta matéria integre o relatório sobre o estado do ambiente municipal.

2.4. Um quarto plano de repercussão do princípio do desenvolvimento sustentável no planeamento territorial é a minoração das causas das alterações climáticas.

Os impactes de recentes eventos extremos, tais como ondas de calor, secas, cheias e fogos florestais, demonstram a significativa vulnerabilidade e exposição à variabilidade climática de alguns ecossistemas e de muitos sistemas humanos. Na Europa, estes eventos extremos têm impactes significativos sobre múltiplos setores económicos, assim como efeitos adversos sobre a sociedade e a saúde. Portugal encontra-se entre os países europeus com maior potencial de vulnerabilidade aos impactes das alterações climáticas. A generalidade dos estudos científicos mais recentes aponta a região do sul da Europa como uma das áreas potencialmente mais afetadas pelas alterações climáticas. Os vários países do mundo defrontam-se com um enorme desafio político, subscrito por Portugal e pela União Europeia (UE), um desafio de longo prazo, que é o de reduzir globalmente as emissões programadas a longo prazo - pelo menos num horizonte até 2050 - na ordem dos 50\% em relação aos valores atuais.

Embora a LBPSOTU não faça menção expressa às alterações climáticas, estas estão subjacentes aos fins da política pública de solos, de ordenamento do território e de urbanismo, indicados nas alíneas $j$ ), $k$ ) e $l$ ) do artigo $2 .^{\circ}$, quais sejam "prevenir riscos coletivos e reduzir os seus efeitos nas pessoas e bens", "salvaguardar e valorizar a orla costeira, as margens dos rios e as albufeiras" e "dinamizar as potencialidades das áreas agrícolas, florestais e silvo-pastoris".

É no contexto anteriormente assinalado que a Resolução do Conselho de Ministros n. ${ }^{o}$ 56/2015, de 30 de julho, aprovou o "Quadro Estratégico para a Política Climática", o "Programa Nacional para as Alterações Climáticas" e a "Estratégia Nacional de Adaptação às Alterações Climáticas", determinou que Portugal deve reduzir as suas emissões de gases com efeito de estufa para valores de $-18 \%$ a $-23 \%$ em 2020 e de $-30 \%$ a $-40 \%$ em 2030, face a valores de 2005 e criou a "Comissão Interministerial do Ar e das Alterações Climáticas (CIAAC)", uma estrutura no plano político para o acompanhamento da política climática e das políticas setoriais com impacte nos objetivos nacionais em matéria de ar e alterações climáticas.

Entretanto, a Resolução do Conselho de Ministros n. ${ }^{\circ}$ 53/2020, de 10 de julho, aprovou o Plano Nacional Energia e Clima 2030 (PNEC 2030), manteve em vigor, até 31 de dezembro de 2025, a vigência da Estratégia Nacional para a Adaptação às Alterações Climáticas, aprovada pela Resolução do Conselho de Ministros n. ${ }^{\circ}$ 56/2015, 
de 30 de julho, revogou o Programa Nacional para as Alterações Climáticas 2020/2030, aprovado pela Resolução do Conselho de Ministros n. ${ }^{\circ}$ 56/2015, de 30 de julho, e determinou que a promoção e o acompanhamento do PNEC 2030 seja assegurada pela Comissão Interministerial do Ar, das Alterações Climáticas e da Economia Circular, criada pela Resolução do Conselho de Ministros n. ${ }^{\circ}$ 56/2015, de 30 de julho, redenominando-a Comissão para a Ação Climática (CAC).

Na citada Resolução do Conselho de Ministros n. ${ }^{\circ}$ 53/2020, de 10 de julho, sublinhou-se que Portugal assumiu, em 2016, na Conferência das Partes da Convenção Quadro das Nações Unidas para as Alterações Climáticas, o compromisso de alcançar a neutralidade carbónica até 2050 e realçou-se que, para alcançar a neutralidade carbónica, conforme previsto no RNC 2050, foi estabelecida a redução de emissões de gases com efeito estufa (GEE) para Portugal entre $85 \%$ e $90 \%$ até 2050, face a 2005, e a compensação das restantes emissões, através do sequestro de carbono pelo uso do solo e florestas, em termos de a trajetória de redução de emissões ter sido fixada entre $45 \%$ e $55 \%$ até 2030 , e entre $65 \%$ e $75 \%$ até 2040 , em relação aos valores registados em 2005 . E assumiu-se o compromisso do cumprimento das seguintes metas nacionais do PNEC 2030 para o ano 2030, alinhadas com uma trajetória de neutralidade carbónica até 2050: redução entre 45\% e $55 \%$ das emissões de gases com efeito de estufa, por referência às emissões registadas no ano de 2005; incorporação de 47\% de energia de fontes renováveis no consumo final bruto de energia; redução de $35 \%$ do consumo de energia primária com vista a uma melhor eficiência energética; conseguimento de $15 \%$ de interligações de eletricidade. Nela de destacou a importância do cumprimento das seguintes metas setoriais de redução de emissões de gases com efeito de estufa, por referência às emissões registadas em 2005 : $70 \%$ no setor dos serviços; $35 \%$ no setor residencial; $40 \%$ no setor dos transportes; $11 \%$ no setor da agricultura; e 30\% no setor dos resíduos e águas residuais.

Uma das manifestações mais impressivas das alterações climáticas com repercussões gravosas nos territórios costeiros é a subida do nível das águas do mar. Estudos recentes apontam que $14 \%$ da população portuguesa vive na faixa de dois quilómetros ao longo da linha de preia-mar e, bem assim, que 146 mil pessoas vivem na faixa de risco em 11 municípios do Continente português, as quais podem ficar numa situação vulnerável já em 2050, em face de uma subida média de um metro no nível do mar. Refere-se, a este propósito, no Programa Nacional da Política de Ordenamento do

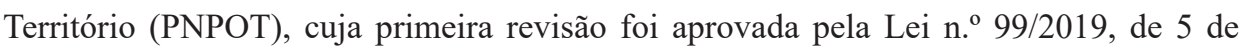
setembro, e cujo modelo de governação para a sua execução consta da Resolução do Conselho de Ministros n. ${ }^{o}$ 48/2020, de 24 de junho, que, “em Portugal, com base no marégrafo de Cascais, registaram-se subidas do nível médio do mar (SNM) de 2,1 mm/ ano entre 1992 e 2004 e 4,0 mm/ano entre 2005 e 2016, seguindo a tendência global", que, "nos Açores, a subida poderá atingir um metro até ao final do século", que o nosso 
País "tem uma orla costeira sujeita a elevada pressão urbana e uma extensão apreciável de litoral baixo e arenoso e baixo rochoso em situação crítica de erosão", fator que "é potenciado pela perspetiva futura da ocorrência mais frequente de fortes temporais".

Os instrumentos de programação e de planeamento territorial que incidem sobre a zona costeira são o mencionado PNPOT, os programas regionais de ordenamento do território, certos programas especiais de ordenamento do território [os programas de ordenamento das áreas protegidas, os programas de ordenamento dos estuários e os programas de ordenamento da orla costeira (POOC)] e os planos municipais e intermunicipais de ordenamento do território, em particular os planos diretores municipais. Mas a modalidade mais importante de programas (anteriormente, planos) especiais de ordenamento do território que visa a proteção e a valorização da zona costeira é, inquestionavelmente, constituída pelos programas de ordenamento da orla costeira (POOC).

Existem vários programas (designados, anteriormente, planos) de ordenamento da orla costeira (POOC), de imputação estadual, que abrangem a totalidade da zona costeira de Portugal continental, ${ }^{11 / 12}$ e que visam promover a utilização regulada e racional da orla costeira, numa ótica de coexistência de usos e atividades diversos, tendo em vista a salvaguarda do meio ambiente, a prevenção do risco e a garantia da segurança dos cidadãos. Disciplinados pelo Decreto-Lei n. ${ }^{\circ}$ 159/2012, de 24 de julho, os POOC incidem sobre a orla costeira, compreendendo, do lado da terra, uma "zona terrestre de proteção" ${ }^{13}$ e, do lado do mar, uma "zona marítima de proteção" ${ }^{14}$ Os POOC têm como principal preocupação proteger os recursos naturais de áreas especialmente sensíveis, como são as que integram a orla costeira, áreas essas que se caracterizam por uma elevada vulnerabilidade ambiental (resultante, sobretudo, do fenómeno da erosão costeira) e por uma grande diversidade de usos, com especial destaque para as atividades económicas ligadas ao turismo, ao recreio e ao lazer. Tais instrumentos de programação territorial

11 Há uma pluralidade de conceitos para designar porções de território de dimensões variáveis, na interface entre a Terra e o Oceano, tais como "litoral", "faixa costeira", "faixa litoral", "orla costeira", "zona costeira", "zona litoral", "área/região costeira" (cf. PORTUGAL, 2007e, p. 35).

12 Tais programas são os POOC de Caminha-Espinho, Ovar-Marinha Grande, Alcobaça-Mafra, Cidadela-São Julião da Barra, Sintra-Sado, Sado-Sines, Sines-Burgau, Burgau-Vilamoura e Vilamoura-Vila Real de Santo António. Sublinhe-se que, entretanto, os POOC de Alcobaça-Mafra e de Cidadela-São Julião da Barra, bem como de parte do POOC de Sintra-Sado, foram substituídos pelo Programa da Orla Costeira de AlcobaçaCabo Espichel, aprovado pela Resolução do Conselho de Ministros n. ${ }^{\circ}$ 66/2019, de 11 de abril.

13 A "zona terrestre de proteção" é composta pela margem das águas do mar e por uma faixa, medida na horizontal, com uma largura de $500 \mathrm{~m}$, contados a partir da linha que limita a margem das águas do mar, podendo ser ajustada para uma largura máxima de $1000 \mathrm{~m}$ quando se justifique acautelar a integração de sistemas biofísicos fundamentais no contexto territorial objeto do programa (artigo 8. ${ }^{\circ}, \mathrm{n}^{\circ}{ }^{\circ}$, do Decreto-Lei n. $\left.{ }^{\circ} 159 / 2012\right)$.

14 A "zona marítima de proteção" é a faixa compreendida entre a linha limite do leito das águas do mar e a batimétrica dos $30 \mathrm{~m}$ referenciada ao zero hidrográfico (artigo 9. ${ }^{\circ}$, n. $^{\circ} 1$, do Decreto-Lei n. ${ }^{\circ}$ 159/2012). 
contêm prescrições que prevalecem sobre os planos intermunicipais de ordenamento do território, quando existam, e sobre os planos municipais de ordenamento do território (artigos 44. ${ }^{\circ}$, n. $^{\circ} 3$, e $78 .^{\circ}$ da LBPSOTU e 3. ${ }^{\circ},{ }^{\circ}{ }^{\circ} 5,27 . .^{\circ},{ }^{\circ}$ 2, $28 .^{\circ}, 29 .^{\circ}, 39 .^{\circ}$ a $51 .^{\circ}, 121 .^{\circ}$ e $129 .{ }^{\circ}$ do RJIGT). ${ }^{15}$

É necessário, no entanto, dar mais um passo, em termos de as entidades intermunicipais e os municípios desempenharem também um papel importante no combate às alterações climáticas. A nível dos municípios costeiros portugueses, é urgente que os mesmos disponham de uma cartografia de risco minuciosa para incorporação nos respetivos planos diretores municipais, de modo a orientarem o planeamento do seu território. Dentro desta linha, está em curso a elaboração de um "plano metropolitano de adaptação às alterações climáticas", que coenvolve 18 municípios da Grande Lisboa, com implicações no redesenho urbano, na aposta em espaços verdes e em investimentos nas estruturas de captação de águas.

\section{Um planeamento urbanístico socialmente sustentável}

O planeamento urbanístico socialmente sustentável caracteriza-se, em primeiro lugar, pelo combate à segregação espacial urbana. É sabido que esta se apresenta como a marca territorial da exclusão e injustiça social, que, na sua vertente mais radical, pode manifestar-se na constituição de guetos, ou seja, de concentrações de populações desfavorecidas em territórios circunscritos caracterizados por uma degradação física e social, os quais são fonte de instabilidade social, marginalidade, violência e delinquência. Situações estas que tendem a agravar-se quando tais guetos surgem associados a fenómenos de imigração e de segregação por classe ou por etnia. (OLIVEIRA, 2011, p. 107-121; MIRANDA, 2012, p. 181-185).

Para contrariar o fenómeno da segregação espacial urbana, devem os planos territoriais incluir novas preocupações, como sejam políticas sociais e culturais, políticas de combate à pobreza e de apoio a setores da população mais vulneráveis, políticas de habitação e de disponibilidade de serviços púbicos de saúde e de educação, políticas de transportes públicos e de acessibilidade e mobilidade urbanas. Devem, além disso, promover o desenvolvimento de políticas urbanas vocacionadas para a criação e manutenção de emprego em bairros em dificuldades e para a sua abertura ao resto da cidade. Em suma, os planos territoriais devem dar uma especial ênfase, no conjunto dos interesses a ponderar, aos interesses sociais, em especial aos dos cidadãos mais desfavorecidos. $\mathrm{O}$ que aponta para uma deslocação do que tem sido o centro de gravidade do planeamento

15 Para mais desenvolvimentos, Alves Correia, F. (2009, p. 252-267). 
territorial, traduzido numa visão proprietarista e economicista do fenómeno urbano, para as políticas de coesão social.

Em segundo lugar, o planeamento urbanístico socialmente sustentável promove ou mesmo impõe a coexistência, na mesma zona, de usos urbanísticos variados, desde que compatíveis entre si (residencial, comercial, serviços e pequenas indústrias não poluentes), ${ }^{16}$ e consagra tipologias de habitação destinadas a estratos sociais diferentes (mais favorecidos e menos favorecidos). O planeamento urbanístico socialmente sustentável estimula, assim, o surgimento de um urbanismo de "mescla social" ("mixité sociale"), fomentador da convivência, num mesmo espaço, de pessoas pertencentes a classes sociais ou grupos sociais diferentes, e de um urbanismo assente num zonamento plurifuncional.

Uma das técnicas de combate ao fenómeno da segregação espacial urbana por parte do planeamento urbanístico é a do zonamento de inclusão (inclusionary zoning), em substituição da técnica de zonamento que tem sido normalmente utilizada, a qual tem consistido, em muitos casos, num zonamento de exclusão (exclusionary zoning). $\mathrm{O}$ zonamento de inclusão é uma técnica que alcançou nos Estados Unidos da América um especial desenvolvimento, pretendendo-se com a mesma corrigir soluções urbanísticas que tiveram efeitos de segregação urbana e de exclusão de minorias étnicas mais desfavorecidas, tais como a fixação de lotes grandes edificáveis, a imposição de áreas mínimas de espaço em cada piso, a limitação do número de habitações a construir, o estabelecimento de restrições à construção de habitações multifamiliares e a ausência de áreas reservadas para habitação social ou de rendas baixas. (ARNOLD, 1998, p. 76).

16 Sublinhe-se que esta mistura de usos, decorrente do zonamento plurifuncional, composta por um uso dominante e usos complementares deste e compativeis com ele, é estimulada pelo nosso RJIGT, na medida em que a classificação e qualificação do solo, operadas pelos planos municipais, definem os usos dominantes de determinadas áreas ou zonas do território, donde decorre a admissibilidade e a conveniência de no mesmo serem associados outros usos complementares daqueles ou com eles compatíveis (artigos $70{ }^{\circ}$ a 74. ${ }^{\circ}$ do RJIGT). Sobre esta matéria, Carvalho (2003, p. 307-311).

No mesmo sentido, o Plano Regional de Ordenamento do Território do Alentejo, aprovado pela Resolução do Conselho de Ministros n. ${ }^{\circ}$ 53/2010, de 2 de agosto, retificada pela Declaração de Retificação n. ${ }^{\circ} 30$ A/2010, de 1 de outubro, estabelece, no conjunto das normas orientadoras e de natureza operacional relativas ao planeamento e edificação em solo urbano, um elenco de diretivas, nos seguintes termos: "144 - A Administração Local deve contrariar a monofuncionalidade e promover a valorização de centralidades intraurbanas, nomeadamente, nas sedes dos concelhos, através de:

a) Preservar uma diversidade funcional nas áreas urbanas consolidadas e nos solos urbanos programados;

b) Evitar a monofuncionalidade nas intervenções urbanísticas de grande dimensão e garantir uma maior relação entre as centralidades urbanas e as infraestruturas principais preexistentes;

c) Qualificar as centralidades urbanas existentes, beneficiando o espaço público, concentrando equipamentos estruturantes e localizando atividades (de lazer, restauração, comércio) que promovam a atratividade urbana". 
Uma segunda técnica de luta contra a segregação social é a da fixação pelo legislador de standards no domínio habitacional, ${ }^{17}$ muitas vezes quantificados, impondo aos instrumentos de planeamento territorial ou a previsão de áreas destinadas a habitação social ou mesmo a construção de habitações para cidadãos economicamente desfavorecidos. Limitando-nos ao ordenamento jurídico urbanístico português, assim sucedia na anterior Lei de Bases da Política de Ordenamento do Território e de Urbanismo (aprovada pela Lei n. ${ }^{\circ}$ 48/1998, de 11 de agosto, alterada pela Lei n. ${ }^{\circ}$ 54/2007, de 31 de agosto), que estabelecia, no artigo $6 .^{\circ}$, n. $^{\circ} 1$, alínea $g$ ), como objetivo específico da política de ordenamento do território e de urbanismo a aplicação de uma política de habitação que permita resolver as carências existentes, sem perder de vista, como referia a alínea e) do n. ${ }^{\circ} 1$ do mesmo preceito, a necessidade de adequação dos níveis de densificação urbana, impedindo a degradação da qualidade de vida (objetivo específico esse que não está expressamente contemplado na atual LBPSOTU, mas que resulta implicitamente dos fins da política pública de solos, de ordenamento do território e de urbanismo do "desenvolvimento sustentável", da "coesão nacional" e da "inclusão social", indicados nas alíneas b) e c) do artigo 2. ${ }^{\circ}$ desta mesma lei). Assim sucede, igualmente, no vigente RJIGT, que prescreve, no artigo $95^{\circ}$, n. $^{\circ} 1$, que o plano diretor municipal (PDM) estabelece a estratégia de desenvolvimento territorial municipal e a política municipal de solos, de ordenamento do território e de urbanismo, onde se inclui a política de habitação, e estatui, no artigo $96^{\circ},{ }^{\circ} .^{\circ} 1$, alínea $g$ ), a obrigação de os PDM incluírem no seu conteúdo material, inter alia, "a identificação e a delimitação das áreas urbanas, com a definição do sistema urbano municipal e os correspondentes programas na área habitacional, bem como as condições de promoção da regeneração e da reabilitação urbanas e as condições de reconversão das áreas urbanas de génese ilegal"; e determina, no artigo $98 .^{\circ}$, n. $^{\circ} 1$, que o plano de urbanização fornece o quadro de referência para a aplicação das políticas urbanas e, no artigo 99. ${ }^{\circ}$, alínea e), que o mesmo plano tem como conteúdo material, entre o mais, "as condições de aplicação dos instrumentos da política de solos e de política

17 Sobre o conceito de standards urbanísticos, entendidos como determinações materiais de ordenamento estabelecidas pela lei, não com o objetivo de regular diretamente o uso do solo e das construções, mas antes com a finalidade específica de estabelecer critérios de fundo a observar pelo planeamento urbanístico, Alves Correia (2008, p. 668-672), e a bibliografia aí citada. 
urbana previstos na lei, em particular os que respeitam à reabilitação e regeneração de áreas urbanas degradas". ${ }^{18 / 19}$

18 Os preceitos indicados no texto não são mais do que uma concretização do artigo $65 .^{\circ}$ da Constituição da República Portuguesa (CRP), que consagra o direito à habitação, determinando que "todos têm direito, para si e para a sua família, a uma habitação de dimensão adequada, em condições de higiene e conforto e que preserve a intimidade pessoal e a privacidade familiar", e do n. ${ }^{\circ} 2$ do mesmo preceito, que prevê o conjunto de tarefas cometidas ao Estado para realizar aquele direito, nas quais se incluem: a programação e execução de uma política de habitação inserida em planos de ordenamento geral do território e apoiada em planos de urbanização que garantam a existência de uma rede adequada de transportes e de equipamento social; a promoção, em colaboração com as regiões autónomas e com as autarquias locais, da construção de habitações económicas e sociais; o estímulo à construção privada, com subordinação ao interesse geral, e ao acesso à habitação própria ou arrendada; e o incentivo às iniciativas das comunidades locais e das populações, tendentes a resolver os respetivos problemas habitacionais e a fomentar a criação de cooperativas de habitação e a autoconstrução.

A Revisão constitucional de 1997, ao congregar os termos habitação e urbanismo no título do artigo $65 .^{\circ}$ da CRP, acentuou a associação entre o direito do urbanismo e o direito à habitação, em termos de o direito do urbanismo ser uma garantia do direito fundamental a habitação. Além disso, o mesmo preceito constitucional, ao associar o direito à habitação ao urbanismo, liga-o indissoluvelmente às políticas públicas dirigidas à ocupação, uso e transformação racional dos solos, colocando "em evidência o facto de as políticas públicas integrarem prestações sociais que são devidas em razão da garantia do direito a uma habitação adequada". Para uma análise mais aprofundada sobre a configuração jurídico-constitucional do direito à habitação e sobre a política da habitação em Portugal, Alves Correia, F. e Moniz (2010a, p. 137-164) e Garcia (2012, p. 651-667).

19 Outros instrumentos de programação e de planeamento territorial hierarquicamente superiores ao PDM consagram diretrizes e orientações em matéria de políticas habitacionais. Assim sucedia, desde logo, com a primeira versão do Programa Nacional da Política de Ordenamento do Território (PNPOT), aprovado pela Lei n. ${ }^{\circ}$ 58/2007, de 4 de setembro, retificada pela Declaração de Retificação n. ${ }^{\circ}$ 80-A/2007, de 7 de setembro. Identificando como um dos problemas do ordenamento do território a degradação da qualidade de muitas áreas residenciais (sobretudo nas periferias e nos centros históricos das cidades) e a persistência de segmentos da população sem acesso condigno à habitação, o PNPOT previa, como uma das medidas prioritárias a desenvolver, o apoio à mobilidade residencial através da maior eficiência do mercado de arrendamento privado, da alteração e melhoria dos modelos de gestão e qualificação do parque de arrendamento público e de uma melhor adequação e flexibilidade nas condições de financiamento da aquisição de habitação, sem olvidar a situação especial dos imigrantes. Por outro lado, determinando o envolvimento das Administrações central e local, isoladamente ou em parceria com a sociedade civil, no domínio da habitação, de forma a promover a qualidade de vida urbana e o acesso dos cidadãos a uma habitação condigna, segundo critérios de qualidade, equidade, mobilidade e sustentabilidade, o PNPOT estabelecia a necessidade de elaborar e implementar o Plano Estratégico de Habitação (PEH), dinamizar o mercado de arrendamento e o parque habitacional públicos, incentivar o cumprimento de objetivos sociais por parte dos promotores imobiliários (nomeadamente mediante a afetação a habitação social de uma quotaparte da habitação nova ou através do incremento das operações de reabilitação ou de revitalização urbana), desenvolver intervenções sócio urbanísticas em territórios que apresentem fatores de vulnerabilidade crítica, promover a inserção nos instrumentos de planeamento municipal de objetivos sociais de combate à segregação urbana e de acolhimento e integração dos imigrantes e minorias étnicas (v. g., através da institucionalização dos princípios da diversidade nos modelos de usos e tipologias de habitação), concluir o Programa Especial de Realojamento (PER) e implementar programas municipais de resposta às graves carências habitacionais, reforçando a solução da reabilitação do parque devoluto relativamente à construção nova.

E o mesmo sucede com a atual versão do PNPOT, aprovada pela Lei n. ${ }^{\circ}$ 99/2019, de 5 de setembro, que estabelece como medidas de política habitacional "promover uma política de habitação integrada", concretizando "o direito à habitação condigna e a uma melhor qualidade de vida", alargando os "beneficiários da política de habitação e da dimensão do parque habitacional com apoio público", reduzindo a "sobrecarga 
Vale a pena enunciar, ainda que em termos muito breves, os instrumentos normativos mais recentes corporizadores das políticas públicas em matéria de habitação, que coenvolvem o Estado, as Regiões Autónomas dos Açores e da Madeira e os municípios. São os seguintes: a Resolução do Conselho de Ministros n. ${ }^{\circ}$ 50-A/2018, de 2 de maio, que aprovou "o sentido estratégico, objetivos e instrumentos de atuação para uma Nova Geração de Políticas de Habitação"; a Lei de Bases da Habitação, constante Lei n. ${ }^{\circ}$ 83/2019, de 3 de setembro; a Lei n. ${ }^{\circ}$ 10/2019, de 7 de fevereiro, que cria o Observatório da Habitação, do Arrendamento e da Reabilitação Urbana para acompanhamento do mercado de arrendamento urbano nacional; a Lei n. ${ }^{\circ}$ 12/2019, de 12 de fevereiro, que proíbe e pune o assédio no arrendamento, procedendo à quinta alteração ao Novo Regime do Arrendamento Urbano; a Lei n. ${ }^{\circ}$ 6/2006, de 27 de fevereiro, alterada por vários diplomas posteriores, o último dos quais a Lei n. ${ }^{\circ}$ 2/2020, de 31 de março, que aprova o Novo Regime Jurídico do Arrendamento Urbano; a Lei n. ${ }^{\circ}$ 13/2019, de 12 de fevereiro (retificada pela Declaração de Retificação n. ${ }^{\circ}$ 11/2019, DR, 1. ${ }^{a}$ Série, de 4 de abril), que aprovou medidas destinadas a corrigir situações de desequilíbrio entre arrendatários e senhorios, a reforçar a segurança e a estabilidade do arrendamento urbano e a proteger arrendatários em situação de especial fragilidade; o Decreto-Lei n. ${ }^{\circ}$ 68/2019, de 22 de maio, que cria o Programa de Arrendamento Acessível; o Decreto-Lei n. ${ }^{\circ}$ 69/2019, de 22 de maio, que estabelece o regime especial dos contratos de seguro de arrendamento acessível no âmbito do Programa de Arrendamento Acessível; as Portarias n. ${ }^{\text {os }}$ 175/2019, 176/2019 e 177/2019, todas de 6 de junho, que regulamentam disposições do Decreto-Lei n. ${ }^{\circ}$ 68/2019, relativo ao Programa de Arrendamento Acessível; o Decreto-Lei n. ${ }^{\circ}$ 94/2019, de 16 de julho, que aprova o plano de reabilitação de património público para arrendamento acessível; o Decreto-Lei n. ${ }^{\circ} 1 / 2020$, de 9 de janeiro, que disciplina o Direito Real de Habitação Duradoura; a Lei n. ${ }^{\circ}$ 50/2018, de 16 de agosto, que estabelece o quadro da transferência de competências para as autarquias locais e para as entidades intermunicipais, nelas incluindo a habitação, e o Decreto-Lei n. ${ }^{\circ}$ 105/2018, de 29 de novembro, que concretiza a transferência de competências para os órgãos municipais no domínio da habitação; o Decreto-Lei n. ${ }^{\circ}$ 67/2019, de 21 de maio, que aprova o agravamento do imposto municipal sobre imóveis relativamente a prédios devolutos em zonas de pressão urbanística; a Lei n. ${ }^{\circ} 43 / 2019$, de 21 de junho, que condensa a interpretação autêntica do n. 7 do artigo 1.041. ${ }^{\circ}$ do Código Civil, aditado pelo artigo $2 .^{\circ}$ da Lei n. ${ }^{\circ} 13 / 2019$, de 12 de fevereiro, que

das despesas com habitação no regime de arrendamento" e aumentando o "peso da reabilitação no total de fogos concluídos".

Acresce que o Plano Regional de Ordenamento do Território do Alentejo, anteriormente citado, encerra, no conjunto das normas orientadoras e de natureza operacional relativas ao planeamento e edificação em solo urbano, um conjunto de diretivas sobre políticas municipais de habitação. (fr. artigo $145 .^{\circ}$, alíneas $a$ ), b), c) e d) (PORTUGAL, 2010a, p. 4.372-4.374). 
estabelece medidas destinadas a corrigir situações de desequilíbrio entre arrendatários e senhorios, a reforçar a segurança e a estabilidade do arrendamento urbano e a proteger arrendatários em situação de especial fragilidade; e a Resolução do Conselho de Ministros n. ${ }^{\circ}$ 52-A/2020, de 1 de julho, que aprova o Programa Bairros Saudáveis.

\section{Um planeamento de contenção urbanística}

Um dos fins da nova LBPSOTU é, de acordo com o seu artigo 2. ${ }^{\circ}$, alínea $c$ ), "reforçar a coesão nacional, organizando o território de modo a conter a expansão urbana e a edificação dispersa". Este objetivo está espelhado, desde logo, no artigo $10{ }^{\circ}$ da mesma lei, que prevê apenas duas classes de solo: "solo rústico" e "solo urbano". O solo rústico é "aquele que, pela sua reconhecida aptidão, se destine, nomeadamente, ao aproveitamento agrícola, pecuário, florestal, à conservação, valorização e exploração de recursos naturais, de recursos geológicos ou de recursos energéticos, assim como o que se destina a espaços naturais, culturais, de turismo, recreio e lazer ou à proteção de riscos, ainda que seja ocupado por infraestruturas e aquele que não seja classificado como urbano". O solo urbano é "o que está total ou parcialmente urbanizado ou edificado e, como tal, afeto em plano territorial à urbanização ou à edificação". Esta opção por uma lógica de efetiva e adequada afetação do solo urbano ao solo parcial ou totalmente urbanizado ou edificado tem como consequência o estreitamento da noção de solo urbano, a eliminação da categoria de solo urbanizável e a consagração do princípio da sustentabilidade territorial, cujo sentido é o de que a transformação do solo rústico em urbano deve ser limitada ao indispensável, sustentável do ponto de vista económico e financeiro e fundada em indicadores demográficos e de níveis de oferta e de procura de solo urbano.

Este novo regime do uso do solo - que estabelece as regras de ocupação, transformação e utilização do solo e é uma das tarefas fundamentais exercidas pelos planos intermunicipais e municipais, através da classificação e da qualificação do solo, como prescrevem os artigos $70 .^{\circ}$ a $74 .^{\circ}$ do RJIGT - impõe duas condições para que o solo seja reconhecido como urbano: uma fáctica, traduzida na circunstância de estar já total ou parcialmente urbanizado ou edificado e outra jurídica, consubstanciada em estar afeto em plano territorial à urbanização ou edificação. De modo semelhante se passam as coisas quanto ao solo rústico. Para ser reputado como tal, necessita de possuir reconhecidas aptidões para o aproveitamento agrícola, pecuário, florestal ou similar e de não ser classificado como urbano pelo plano territorial. Subjacente a este novo regime, caracterizado pela negação da classificação como urbanos de solos que não tenham já uma "pegada" urbana, está o objetivo de conter a expansão urbana e a urbanização dispersa e de direcionar preferencialmente o urbanismo do futuro para a reabilitação urbana. 
Especialmente exigentes são os requisitos para a reclassificação do solo rústico em solo urbano. A mesma tem caráter excecional, está dependente da demonstração da sua sustentabilidade económica e financeira, traduzida na comprovação da indisponibilidade de solo urbano, na área urbana existente, para a finalidade em concreto, do impacto da carga urbanística proposta no sistema de infraestruturas existente e da viabilidade económico-financeira da proposta, incluindo a identificação dos sujeitos responsáveis pelo financiamento (artigos $72 .^{\circ}$, n. $^{\text {os }} 1$ e 3 , do RJGT e $8 .^{\circ}$, n. ${ }^{\circ} 5$, do DecretoRegulamentar n. ${ }^{\circ}$ 15/2015, de 19 de agosto), e implica a fixação, por via contratual, dos encargos urbanísticos das operações, do respetivo prazo de execução e das condições de redistribuição de benefícios e encargos, considerando todos os custos urbanísticos envolvidos (artigo 72. ${ }^{\circ}$, n. $^{\circ} 2$, do RJIGT). A excecionalidade da conversão do solo rústico em solo urbano revela-se, ainda, por um lado, no modo como é operacionalizada: somente através dos procedimentos de elaboração, de revisão ou de alteração de planos de pormenor com efeitos registais, acompanhados do respetivo contrato de urbanização, salvo se a conversão se destinar exclusivamente à execução de infraestruturas e de equipamentos de utilização coletiva, situação na qual pode ser utilizada a via dos procedimentos de elaboração, de revisão ou de alteração de quaisquer planos territoriais, nos quais é fixado o respetivo prazo de execução (artigo $72 .^{\circ}$, n..$^{\text {os }} 4$ e 6 , do RJIGT). E, por outro lado, na consequência decorrente da não realização das operações urbanísticas previstas, findo o prazo fixado para a execução do plano: a caducidade automática, total ou parcial, da classificação do solo como urbano, sem prejuízo das faculdades urbanísticas adquiridas mediante título urbanístico, nos termos da lei (artigo $72 .^{\circ}$, n. $^{\circ} 8$, do RJIGT).

\section{Um planeamento urbanístico que toma em consideração a mobilidade urbana}

Ainda que a LBPSOTU não contenha uma norma específica sobre a matéria da mobilidade, é inegável que as questões relacionadas com este problema não passaram despercebidas ao legislador português. Desde logo, entre os fins da política pública de solos, de ordenamento do território e de urbanismo contam-se o reforço da igualdade de oportunidades dos cidadãos no acesso às infraestruturas, equipamentos, serviços e funções urbanas, a promoção da qualidade de vida das populações, bem como a racionalização, reabilitação e modernização dos centros urbanos [artigo 2. , alíneas $c$ ), f) e g)]. Por sua vez, em matéria de gestão territorial, o diploma elege como tarefas públicas a rentabilização de infraestruturas, evitando a extensão desnecessária das redes e dos perímetros urbanos, e racionalizando o aproveitamento das áreas intersticiais, assim como a revitalização dos centros históricos e dos elementos do património cultural [artigo 37. ${ }^{\circ}$, alíneas f) e $h$ )].

Mas se na LBPSOTU encontramos um lastro de preocupações em matéria de mobilidade, na sua articulação com o planeamento territorial, é no RJIGT que nos 
deparamos com um relacionamento mais profundo entre os instrumentos de gestão territorial e a mobilidade. Isso mesmo decorre quer do artigo $10 .^{\circ}$ (quando impõe, em geral, a identificação das redes de transporte e mobilidade nos programas e planos territoriais), quer dos seus concretizadores artigos $20{ }^{\circ}$ e $21 .^{\circ}$ : o primeiro preceito determina que as redes rodoviária e ferroviária nacionais, as estradas regionais, os portos e aeroportos, bem como a respetiva articulação com as redes locais de transporte e mobilidade, são identificados e definidos nos programas e nos planos territoriais, a implicar que as várias entidades envolvidas desenvolvam procedimentos de informação destinados a garantir a coerência do sistema; a segunda disposição impõe que as redes de infraestruturas e os equipamentos de nível fundamental que promovem a qualidade de vida, apoiam a atividade económica e asseguram a otimização do acesso à cultura, à educação, à justiça, à saúde, à segurança social, ao desporto e ao lazer sejam identificados nos programas e nos planos territoriais, os quais definem uma estratégia coerente de instalação, de conservação e de desenvolvimento das infraestruturas ou equipamentos, considerando as necessidades sociais e culturais da população e as perspetivas de evolução económicas e sociais.

Estas ideias surgem concretizadas a propósito e no contexto dos diversos instrumentos de gestão territorial. Assim, o PNPOT, cuja primeira revisão foi, como dissemos, aprovada pela Lei n. ${ }^{\circ}$ 99/2019, de 5 de setembro, avança explicitamente com as questões da mobilidade, prevendo uma articulação mais estreita entre a transformação energética e as novas soluções de mobilidade (veículos, sistemas de propulsão e gestão integrada a longa distância e no espaço urbano), identificando como tendência de evolução o impulso conferido a novas soluções tecnológicas para o desenvolvimento "inteligente" das cidades, contribuindo para uma gestão e utilização dos recursos de forma mais eficiente e para a melhoria da qualidade de vida dos cidadãos, em resposta, nomeadamente, às novas exigências de mobilidade e com preferência por hábitos de mobilidade suave. Neste contexto, as áreas urbanas deverão promover modelos urbanos mais compatíveis com as especificidades físicas do território (clima, relevo, recursos hídricos, entre outros), demonstrando maior sensibilidade aos problemas e oportunidades ambientais. As preocupações com a renaturalização das cidades, a reabilitação urbana, a redução do consumo de energia e água, a mobilidade urbana sustentável e a utilização de energias alternativas favorecem o crescimento verde e um desenvolvimento urbano mais sustentável, com repercussões ao nível da saúde e da qualidade de vida dos cidadãos. ${ }^{20}$

20 Repare-se que um dos eixos de ação do PNPOT reside precisamente no reforço e integração das redes de acessibilidade e de mobilidade, visando a coordenação de todas as infraestruturas de transporte e da necessidade de privilegiar os transportes coletivos, melhorar o desempenho ambiental dos transportes (em especial, rodoviários, e incluindo o transporte flexível) e incentivar a utilização dos serviços partilhados (táxi coletivo, van, car e bike-sharing).

Sobre este tema, para mais desenvolvimentos, Alves Correia, F. e Moniz (2010b). 
Nos termos da LBPSOTU, também os programas regionais se debruçam sobre questões relacionadas com a mobilidade: de acordo com a alínea a) do n. ${ }^{\circ} 1$ do artigo 41. ${ }^{\circ}$, os programas regionais estabelecem as opções estratégicas de organização do território regional, tendo em conta o sistema urbano, as infraestruturas e os equipamentos de utilização coletiva de interesse regional, bem como as áreas de interesse regional em termos agrícolas, florestais, ambientais, ecológicos e económicos, integrando redes nacionais de infraestruturas, de mobilidade e de equipamentos de utilização coletiva com expressão regional [vide também o artigo $54 .^{\circ}$, n. $^{\circ} 1$, alínea $a$ ), do RJIGT]. A inclusão nos atualmente designados programas (anteriormente, planos) regionais de ordenamento do território ${ }^{21}$ das matérias relativas à mobilidade representa uma tradição do sistema jurídico português (mesmo ao abrigo da legislação de enquadramento anterior): em programas mais antigos, sobretudo quando incidentes sobre regiões mais densamente povoadas ou com uma malha urbana economicamente mais forte, um dos propósitos do planeamento regional reside já na melhoria da mobilidade territorial, através do reforço das acessibilidades e da organização e gestão de sistemas de transporte sustentáveis, fiáveis e competitivos. ${ }^{22}$

Por sua vez, também nos planos territoriais de âmbito municipal, são consagradas disposições atinentes aos problemas da mobilidade - em especial, no plano diretor municipal (de onde constam a estratégia de desenvolvimento territorial municipal, o modelo territorial municipal, as opções de localização e de gestão de equipamentos de utilização coletiva e as relações de interdependência com os municípios vizinhos ${ }^{23}$ ), do plano de urbanização, na medida em que, cabendo-lhe a concretização do plano diretor municipal, define a localização das infraestruturas e dos equipamentos coletivos

$21 \quad$ Alves Correia, F. (2018b, p. 521-538), em especial, p. 525 e 526.

22 Veja-se, por exemplo, o Plano Regional de Ordenamento do Território da Área Metropolitana de Lisboa, aprovado pela Resolução do Conselho de Ministros n. ${ }^{\circ}$ 68/2002, de 8 de abril. Considerando o aumento da utilização do transporte individual (com o consequente aumento do congestionamento de tráfego), este plano preconizava uma atitude mais dirigista da Administração, a qual passaria, num primeiro momento, por definir prioridades de investimento e de intervenção de forma integrada, e tendo igualmente em conta uma perspetiva ambiental (diminuição de emissões poluentes e de ruído no espaço urbano e periurbano), visando aumentar a atratividade global do sistema de transportes coletivos, para desenvolver, em seguida, uma verdadeira política de mobilidade sustentável, onde se atuaria simultaneamente em todos os modos de transporte.

23 Do conteúdo material do plano diretor municipal constam, inter alia, a caracterização, ou a sua atualização, económica, social e biofísica, incluindo a identificação dos valores culturais, do sistema urbano e das redes de transportes e de equipamentos, os critérios de sustentabilidade a adotar, bem como os meios disponíveis e as ações propostas, que sejam necessários à proteção dos valores e dos recursos naturais, recursos hídricos, culturais, agrícolas e florestais, e a identificação da estrutura ecológica municipal, assim como a definição de estratégias e dos critérios de localização, de distribuição e de desenvolvimento das atividades industriais, turísticas, comerciais e de serviços [artigo $96^{\circ},{ }^{\circ} .^{\circ} 1$, alíneas a), c) e e), do RJIGT]. 
principais, ${ }^{24}$ ou do plano de pormenor ${ }^{25}$ (artigos $43 .^{\circ},{ }^{\text {nos }} 3,4$ e 5 , da LBPSOTU e $95 .^{\circ}$ e seguintes e $98 .^{\circ}$ e seguintes do RJIGT). Repare-se, aliás, que o plano diretor municipal se apresenta como um documento de matriz híbrida, simultaneamente estratégico, no que se refere às opções de desenvolvimento local, e regulamentar, no sentido de que lhe compete a especificação qualitativa e quantitativa dos índices, indicadores e parâmetros de referência de uso do solo, que, na ausência de planos mais concretos, são aplicáveis de forma supletiva. (ALVES CORREIA, F., 2008, p. 352). O conteúdo destes planos oferece já as regras de localização de parques de estacionamento, vias especificamente destinadas a determinados veículos ou meios de transporte (por exemplo, ciclovias) ${ }^{26}$ ou com acesso exclusivamente pedonal.

A circunstância de os programas e planos territoriais já conterem disposições que incorporam as estruturas de mobilidade (em especial, a localização e as exigências das infraestruturas de transportes) não oblitera que, a nível setorial, se desenvolva outro tipo de instrumentos especificamente dirigidos à solução dos problemas relacionados com a mobilidade. Neste horizonte, salientamos o Plano Estratégico dos Transportes e Infraestruturas - PETI 3+ (de nível nacional), ${ }^{27}$ assim como os planos de mobilidade urbana sustentável (municipais ou intermunicipais), documentos de natureza estratégica elaborados em cumprimento ${ }^{28}$ das medidas de concretização do Portugal 2020 ${ }^{29}$

${ }_{24}$ O conteúdo material do plano de urbanização envolve, em particular, a conceção geral da organização urbana, a partir da qualificação do solo, definindo a rede viária estruturante, a localização de equipamentos de uso e interesse coletivo, a estrutura ecológica, bem como o sistema urbano de circulação, de transporte público e privado e de estacionamento, assim como a adequação do perímetro urbano definido no plano diretor municipal ou no plano diretor intermunicipal, em função do zonamento e da conceção geral da organização urbana definidos, incluindo, nomeadamente, o traçado e o dimensionamento das redes de infraestruturas gerais que estruturam o território, fixando os respetivos espaços-canal, os critérios de localização e de inserção urbanística e o dimensionamento dos equipamentos de utilização coletiva [artigo 99. ${ }^{\circ}$, alíneas $b$ ) e $d$ ), do RJIGT].

25 A este cabe estabelecer, designadamente, o desenho urbano, exprimindo a definição dos espaços públicos, incluindo os espaços de circulação viária e pedonal e de estacionamento, bem como o respetivo tratamento, a localização de equipamentos e zonas verdes e a implantação das redes de infraestruturas [artigo $102 .^{\circ}$, n. $^{\circ}$ 1, alíneas c) e $g$ ), do RJIGT].

26 Naturalmente, quando existam vias destinadas a certos tipos de transporte (v. g., ciclovias), todos os demais veículos se encontram proibidos de aí transitar, sob pena de incorrerem em responsabilidade contraordenacional (artigos $76 .^{\circ}$ e $77 .^{\circ}$ do Código da Estrada).

27 Aprovado pela Resolução do Conselho de Ministros n. ${ }^{\circ}$ 61-A/2015, de 20 de agosto, visando aprofundar o desiderato da mobilidade sustentável, eleito como tema do anterior Plano Estratégico de Transportes, aprovado pela Resolução do Conselho de Ministros n. ${ }^{\circ} 45 / 2011$, de 10 de novembro.

28 Uma das propostas do "pacote de mobilidade" sugeridas pelo IMT consistia em tornar obrigatória, por via legislativa, a elaboração destes planos (atualmente apenas previstos para as áreas metropolitanas de Lisboa e Porto). Vejam-se as Diretrizes Nacionais para a Mobilidade, IMTT (2012, p. 30 et seq.).

29 Sobre o tema da mobilidade urbana, para mais desenvolvimentos, Alves Correia, F. e Moniz (2010b). 
6. Um planeamento urbanístico aberto à participação dos cidadãos, à concertação e à contratualização

Desde a segunda metade do século XX, assiste-se a um incremento da participação dos cidadãos na atividade administrativa - em especial, da participação procedimental -, que postula que estes sejam vistos como colaboradores da administração e não como meros destinatários da ação administrativa. Tal deve-se a uma necessidade de "democratizar a democracia", enquanto expressão da insuficiência legitimadora dos mecanismos representativos oriundos do modelo liberal, através do aprofundamento da democracia participativa.

À democratização do procedimento importa que os cidadãos e a administração nele apareçam face a face, enquanto titulares de situações subjetivas ativas e passivas recíprocas. Desta forma, os cidadãos não são reduzidos a objeto daquele poder, nem são submetidos a uma "integração" no seio da organização administrativa pública, ficando colocados em posição de intervir no efetivo exercício do poder público.

No ordenamento jurídico português, o princípio da participação democrática é passível de ser entendido em termos constitucionais como participação dos interessados na gestão dos serviços administrativos (artigo 267. ${ }^{\circ}$, n. ${ }^{\circ} 1$, da CRP) e como participação direta nas decisões que lhes digam respeito (artigo 267. ${ }^{\circ}, \mathrm{n} .^{\circ} 4$, da CRP).

$\mathrm{O}$ desenvolvimento das manifestações do princípio da participação e o incentivo à participação surgem como tarefas fundamentais do Estado [artigo 9. ${ }^{\circ}$, alínea c), da CRP], sendo o aprofundamento da democracia participativa um dos objetivos do próprio Estado de Direito democrático (artigo 2. ${ }^{\circ}$ da CRP).

No campo específico do planeamento urbanístico, a participação dos cidadãos tem, desde logo, lugar nos procedimentos de elaboração, alteração e revisão dos planos, cuja credencial constitucional específica se encontra no artigo $65 .^{\circ}$, n. $^{\circ} 5$, da CRP. Este estabelece que "é garantida a participação dos interessados na elaboração dos instrumentos de planeamento urbanístico e de quaisquer outros instrumentos de planeamento físico do território".

A mesma tem como fundamento geral a superação do modelo administrativo clássico autoritário, centralizado e burocrático próprio da ideologia liberal e da conceção individualista do Estado, cuja forma de ação típica era a decisão unilateral, autoritária, suscetível de ser imposta aos particulares, se necessário pela força, e entronca no fenómeno da expansão do movimento participativo, que, nas últimas décadas, inundou, nos diferentes países, em especial os europeus, múltiplos setores da organização e da atividade administrativas - participação essa com a qual se pretende atingir vários objetivos: resolver os problemas da falta de conhecimento e de experiência da Administração Pública indispensáveis à escolha das soluções mais adequadas, sobretudo no domínio das 
relações económicas e sociais; contribuir para o aumento da eficiência da Administração, já que as medidas adotadas contam com a boa vontade e o espírito de colaboração dos particulares; estabelecer o contacto direto entre a Administração e os administrados, que funciona como meio de impedir a despersonalização e de evitar os desvios burocráticos da função administrativa; e aprofundar a realização do espírito democrático, que exige não só uma participação episódica na vida política através da designação dos governantes, mas também uma associação ativa dos cidadãos à condução da Administração. Mas tem também um fundamento específico: consiste ele na necessidade de compensar a amplitude do poder discricionário que caracteriza a atividade de planificação com uma exigente e aprofundada participação dos interessados.

A nível do direito ordinário, encontramos, desde logo, o artigo 3. ${ }^{\circ}$, alínea g), da LBPSOTU, que indica como um dos princípios gerais das políticas públicas e das atuações administrativas em matéria de solos, de ordenamento do território e de urbanismo a "participação dos cidadãos, reforçando o acesso à informação e à intervenção nos procedimentos de elaboração, execução, avaliação e revisão dos programas e planos territoriais". E no artigo 6. ${ }^{\circ}$, n. ${ }^{\circ}$ 1, do RJIGT encontramos uma norma de teor idêntico, ao prescrever que "todas as pessoas, singulares e coletivas, incluindo as associações representativas dos interesses ambientais, económicos, sociais e culturais, têm o direito de participar na elaboração, na alteração, na revisão, na execução e na avaliação dos programas e dos planos territoriais".

Não é este o momento adequado para desenvolver os vários aspetos relativos à participação dos interessados nos procedimentos de elaboração, alteração e revisão dos planos. Adiantamos tão-só que são titulares do direito de participação um círculo muito amplo de cidadãos, isto é, não apenas os proprietários ou os titulares de outros direitos reais que incidam sobre um imóvel situado no âmbito espacial de aplicação do plano, mas também aqueles que sejam portadores de um interesse económico ou ideal ou sejam simplesmente "cidadãos" preocupados com um correto planeamento urbanístico e com a melhoria da qualidade de vida do aglomerado onde habitam.

No tocante às formas de participação, o perímetro de proteção do direito de participação abarca a participação uti singuli e uti cives ou, noutros termos, a participação subjetiva (a que tem como finalidade tutelar os direitos e os interesses legalmente protegidos dos particulares) e objetiva (a que tem como fim levar ao conhecimento da Administração todos os factos, interesses e circunstâncias objetivamente relevantes para a elaboração do plano), bem como a participação individual e coletiva (conforme seja levada a cabo pelo administrado entendido singularmente ou pelos grupos ou estruturas sociais organizadas) e a participação direta e indireta (ou seja, a que é realizada pelos indivíduos interessados e a que é exercida pelos delegados ou representantes dos grupos sociais organizados). 
Quanto ao grau de intensidade ou de profundidade da participação, a norma constitucional engloba a participação-audição ou participação-auscultação e a participação-negociação ou concertação.

Relativamente aos momentos da participação, o direito de participação impõe uma participação que tenha lugar logo após a divulgação da decisão ou deliberação de elaboração do plano, ou, pelo menos, durante a elaboração da proposta do plano - modalidade participativa inspirada no instituto do direito alemão da "participação preventiva dos cidadãos" (vorgezogene Bürgerbeteiligung) ou da "participação tempestiva dos cidadãos" (frühzeitige Bürgerbeteiligung) -, bem como uma participação que verse sobre a proposta do plano, por via de regra, no período de discussão pública da mesma - participação esta que, na esteira da doutrina alemã, podemos apelidar de "participação sucessiva ou formal" (förmliche Bürgerbeteiligung).

Finalmente, o direito de participação não pode deixar de abranger os mecanismos considerados essenciais para garantir a sua eficácia. A eficácia deste direitoque não passa, como é óbvio, pela atribuição ao interessado de um direito a ver acolhidas pela Administração as suas sugestões, observações ou reclamações - pressupõe, por um lado, o fornecimento aos interessados de todas as informações relevantes sobre os objetivos do plano e sobre as opções que nele se pretendem consagrar, bem como sobre o estádio dos trabalhos e a evolução do procedimento de elaboração do plano, isto é, a satisfação por parte da Administração do direito à informação dos interessados no procedimento administrativo, plasmado no n. ${ }^{\circ} 1$ do artigo $268 .^{\circ}$ da Lei Fundamental (fenómeno este que demonstra a estreita conexão entre o direito à informação e o direito de participação) e, por outro lado, o dever de a Administração examinar e ponderar as reclamações, observações, sugestões e pedidos de esclarecimento apresentados pelos particulares no exercício do seu direito de participação e, bem assim, a obrigação de levar ao conhecimento dos interessados o resultado de tal exame e ponderação.

Todas estas dimensões do direito de participação dos interessados na formação dos planos - dimensões essas que decorrem do artigo $65 .^{\circ}, \mathrm{n}^{\circ}{ }^{\circ}$, da CRP e que devem ser consideradas como necessárias para que aquele direito cumpra uma função compensadora da amplitude do poder discricionário da planificação urbanística - foram contempladas, nos seus aspetos essenciais, na legislação ordinária, sobretudo no domínio do procedimento de elaboração dos planos territoriais direta e imediatamente vinculativos dos particulares, isto é, dos planos intermunicipais e municipais de ordenamento do território. $^{30}$

$30 \quad$ Para mais desenvolvimentos, Alves Correia, F. (2008, p. 147-148 e 445-483). 
O planeamento urbanístico é também um espaço aberto à concertação entre interesses públicos e privados e à contratualização entre os mesmos. Isso resulta, desde logo, do artigo $3 .^{\circ}$, alínea $h$ ), da LBPSOTU, que indica como um dos princípios gerais das políticas públicas e das atuações administrativas em matéria de solos, de ordenamento do território e de urbanismo a "concertação e a contratualização entre interesses públicos e privados, incentivando modelos de atuação baseados na vinculação recíproca entre a iniciativa pública e a privada na concretização dos programas e planos territoriais".

Quanto às figuras contratuais no domínio do planeamento urbanístico, é possível distinguir os contratos para planeamento e os contratos de execução de planos. Estas duas modalidades podem surgir separadas, mas aparecem, frequentemente, unidas na figura dos contratos urbanísticos integrais. Os contratos para planeamento têm uma disciplina específica no artigo $47 .^{\circ}$ da LBPSOTU e nos artigos $79 .^{\circ}$ a $81 .^{\circ}$ do RJGT, estando ainda sujeitos, em termos que agora não podemos precisar, ao Código dos Contratos Públicos (CCP). Por seu lado, os contratos de execução de planos urbanísticos comportam várias espécies, submetidas a regimes jurídicos diversos, os quais têm o seu regime específico espalhado pelo RJIGT, pelo RJUE e pelo Regime Jurídico da Reabilitação Urbana (RJRU), ${ }^{31}$ estando ainda submetidos, também em termos que não podemos agora desenvolver, ao regime do CCP. ${ }^{32}$

\section{Um planeamento urbanístico estimulador da reabilitação urbana}

O estímulo da reabilitação urbana constitui igualmente uma das grandes missões do planeamento urbanístico. Esta constitui uma virtuosa alternativa à expansão urbana e deve ser encarada como uma obrigação de "conservar a alma" das nossas cidades, de construir uma "harmonia entre o passado e o futuro", 33 de corrigir os erros do passado e de criar um quadro de vida de qualidade para que cada um readquira "uma certa arte de viver". A mesma constitui um dos traços característicos do urbanismo pósmoderno e traduz uma das componentes do novo paradigma do urbanismo. ${ }^{34}$ Ela tem ocupado também um lugar de destaque nas políticas da União Europeia, sobretudo através dos programas URBAN I e II de vários instrumentos financeiros, como o FEDER e a Iniciativa JESSICA (Joint European Support for Sustainable Investment in City Areas), e está presente nos grandes objetivos da Estratégia Europa 2020, que são criar, na próxima década, na União Europeia e nos Estados-Membros uma economia inteligente, sustentável

\footnotetext{
31 Aprovado pelo Decreto-Lei n. ${ }^{\circ}$ 307/2009, de 23 de outubro, alterado pela Lei n. ${ }^{\circ} 32 / 2012$, de 14 de agosto, e pelos Decretos-Leis n. ${ }^{\text {ss }} 136 / 2014$, de 9 de setembro, 88/2017, de 27 de julho, e 66/2019, de 21 de maio.

32 Para mais desenvolvimentos, ALVES CORREIA, J. (2009, p. 51 et seq., 2018, p. 396, 713-721 e 753-757).

33 Morand-Deviller (2014, p. 109).

34 Alves Correia, F. (2008 p. 48 et seq. (nota 33), 2010, p. 335-337, 2013, p. 243-247).
} 
e inclusiva, ${ }^{35}$ bem como nos cinco objetivos principais que irão nortear os investimentos da União Europeia (UE) em 2021-2027. ${ }^{36}$

Em Portugal, os instrumentos de financiamento para as obras de reabilitação mais importantes são o "IFRRU 2020" (Instrumento Financeiro para a Reabilitação e Revitalização Urbanas, destinado a apoiar, em condições favoráveis, operações de reabilitação integral de edifícios, com idade igual ou superior a 30 anos, ou, no caso de idade inferior, que demonstrem um nível de conservação igual ou inferior a 2, determinado nos termos do estabelecido pelo Decreto-Lei n. ${ }^{\circ} 266-\mathrm{B} / 2012$, de 31 de dezembro, e a reabilitação de espaços e unidades industriais abandonadas com vista à sua reconversão, bem como a reabilitação de espaço público, associada à reabilitação do edificado) e o "Reabilitar para Arrendar - Habitação Acessível” (o qual tem como objetivo o financiamento de operações de reabilitação de edifícios com idade igual ou superior a 30 anos, que, após reabilitação, deverão destinar-se predominantemente a arrendamento para fins habitacionais, em regime de renda condicionada).

A política de reabilitação urbana não é uma política exclusivamente urbanística, antes incorpora outras políticas, designadamente, a política de proteção e valorização do património cultural, a política de proteção do ambiente, a política de desenvolvimento sustentável, a política de coesão económica, social e territorial e mesmo a política de segurança urbana. Mas o seu vetor urbanístico é o dominante, como resulta claramente do conceito e objetivos fundamentais da reabilitação urbana e dos instrumentos jurídicos por ela utilizados, que são, na sua essência, instrumentos jurídicos urbanísticos. (LOPES, 2010, p. 22-25; OLIVEIRA, 2010, p. 93-120; ALVES CORREIA, J., 2010, p. 93-95).

$\mathrm{Na}$ terminologia europeia, são múltiplas as expressões utilizadas para expressar o fenómeno da "reconstrução da cidade sobre ela própria", com vista a resolver os problemas sociais, económicos, urbanísticos e de arquitetura de certos

35 A reabilitação urbana ocupa também um local de destaque no quadro da quadro comunitário de apoio de

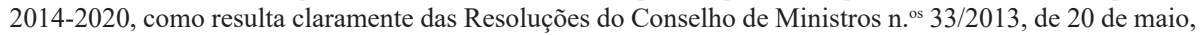
que define os pressupostos do acordo de parceria a negociar entre o Estado Português e a Comissão Europeia, estabelecendo as principais linhas de intervenção dos fundos europeus estruturais e de investimento no ciclo 2014-2020, e 39/2013, de 14 de junho, que aprova um novo modelo institucional de governação dos fundos europeus.

36 Esses objetivos são os seguintes: uma Europa mais inteligente, graças à inovação, à digitalização, à transformação económica e ao apoio às pequenas e médias empresas; uma Europa mais "verde", sem emissões de carbono, aplicando o Acordo de Paris e investindo na transição energética, nas energias renováveis e na luta contra as alterações climáticas; uma Europa mais conectada, com redes de transportes e digitais estratégicas; uma Europa mais social, concretizando o Pilar Europeu dos Direitos Sociais e apoiando o emprego de qualidade, a educação, as competências, a inclusão social e a igualdade de acesso aos cuidados de saúde; e uma Europa mais próxima dos cidadãos, graças ao apoio a estratégias de desenvolvimento a nível local e ao desenvolvimento urbano sustentável na UE. 
quarteirões antigos ou degradados, tais como "renovação urbana", "reconstrução urbana", "regeneração urbana", "reabilitação urbana" e "recomposição urbana" ("renouvellement urbain"). (JÉGOUZO, 2014, p. 15 e 16; MORAND-DEVILLER, 2014, p. 107-109; DEMOUVEAUX, 2002, p. 127-128). Todas estas expressões contêm ínsita a ideia de que tais operações não têm apenas em vista atuações pontuais centradas no edifício ou no imóvel (recuperação do edificado), mas também, e sobretudo, o conjunto do tecido urbano, numa visão integrada, dando relevo à criação ou valorização de infraestruturas, equipamentos e espaços envolventes e procurando suscitar novas evoluções de desenvolvimento social e económico e desenvolver as solidariedades à escala do aglomerado, designadamente através de uma melhor repartição territorial das populações desfavorecidas. Elas são a tradução de uma política urbana que visa, "par une série d'opérations coordonnées, à revaloriser un site urbain dégradé, désaffecté ou paupérisé en y mettant en œuvre les principes de mixité sociale et de diversité urbaine". (DEMOUVEAUX, 2002, p. 129).

Em Portugal, o Decreto-Lei n. ${ }^{\circ}$ 104/2004, de 7 de maio, consagrou um "regime jurídico excecional de reabilitação urbana de zonas históricas e de áreas críticas de recuperação e reconversão urbanística" e definiu a disciplina jurídica das Sociedades de Reabilitação Urbana (SRU). Dado que era este um diploma legal que se estribava numa conceção estreita da reabilitação urbana, essencialmente como recuperação do edificado, e que tinha como objetivo nuclear a regulação de um modelo de gestão das intervenções de reabilitação urbana centrado na constituição, funcionamento, atribuições e poderes das SRU, entendeu o legislador português substituí-lo por um outro, que procedesse ao enquadramento normativo da reabilitação urbana ao nível programático, procedimental e de execução. Esse diploma é o Decreto-Lei n. ${ }^{\circ}$ 30/2009, de 23 de outubro, alterado pela Lei n. ${ }^{\circ}$ 32/2012, de 14 de agosto, e pelos Decretos-Leis n. ${ }^{\text {os }} 136 / 2014$, de 9 de setembro, $88 / 2017$, de 27 de julho, e 66/2019, de 21 de maio, que estabelece o novo regime jurídico da reabilitação urbana (RJRU). ${ }^{37}$ Nele é adotado um conceito amplo de reabilitação urbana, conferindo-se especial relevo não apenas à vertente imobiliária ou patrimonial da reabilitação, mas também à integração e coordenação da intervenção, salientandose a necessidade de atingir soluções coerentes entre os aspetos funcionais, económicos,

37 Por sua vez, o Decreto-Lei n. ${ }^{\circ}$ 53/2014, de 8 de abril, alterado pelo Decreto-Lei n. ${ }^{\circ}$ 194/2015, de 14 de setembro, estabelece um regime excecional e temporário a aplicar à reabilitação de edifícios ou de frações, cuja construção tenha sido concluída há pelo menos 30 anos ou localizados em áreas de reabilitação urbana, sempre que estejam afetos ou se destinem a ser afetos total ou predominantemente ao uso habitacional.

Registe-se que, no exórdio deste diploma legal, se afirma que "a reabilitação do edificado existente em Portugal representa apenas cerca de $6,5 \%$ do total da atividade do sector da construção, bastante aquém da média europeia, situada nos 37\%" e, bem assim, que, "de acordo com os Censos 2011, existem cerca de dois milhões de fogos a necessitar de recuperação, o que representa cerca de $34 \%$ do parque habitacional nacional". 
sociais, culturais e ambientais das áreas a reabilitar. Assim, o artigo 2. ${ }^{\circ}$, alínea $j$ ), daquele decreto-lei define reabilitação urbana como a

forma de intervenção integrada sobre o tecido urbano
existente, em que o património urbanístico e imobiliário é
mantido, no todo ou em parte substancial, e modernizado
através da realização de obras de remodelação ou
beneficiação dos sistemas de infraestruturas urbanas ou
verdes de utilização coletiva e de obras de construção,
reconstrução, ampliação, alteração, conservação ou
demolição dos edifícios.

A importância e a atualidade da reabilitação urbana são assumidas claramente pela LBPSOTU. Com efeito, depois de assinalar no artigo 2. ${ }^{\circ}$, alínea $g$ ), como um dos fins da política pública de solos, de ordenamento do território e de urbanismo "racionalizar, reabilitar e modernizar os centros urbanos, os aglomerados rurais e a coerência dos sistemas em que se inserem" e de assinalar, no artigo $14 .^{\circ}$, n. $^{\circ} 2$, alínea $a$ ), como dever dos proprietários "utilizar, conservar e reabilitar imóveis, designadamente, o edificado existente", define, no artigo 61. ${ }^{\circ}$, os conceitos de reabilitação e regeneração urbanas. A primeira é "a forma de intervenção territorial integrada que visa a valorização do suporte físico de um território, através da realização de obras de reconstrução, recuperação, beneficiação, renovação e modernização do edificado, das infraestruturas, dos serviços de suporte e dos sistemas naturais, bem como de correção de passivos

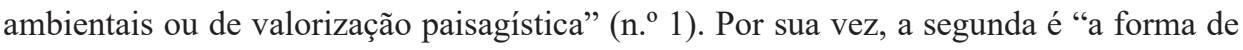
intervenção territorial integrada que combina ações de reabilitação com obras de demolição e construção nova e com medidas adequadas de revitalização económica, social e cultural e de reforço da coesão e do potencial territorial" (n. ${ }^{\circ}$ 2). Destas duas definições parece poder concluir-se que o conceito de regeneração é mais amplo do que o de reabilitação, mas não compreendemos a razão pela qual o legislador - e, para mais, numa lei de bases - veio definir dois conceitos distintos, quando a noção de reabilitação urbana vem sendo entendida atualmente como uma forma lata de intervenção nos tecidos urbanos, independentemente da tipologia das operações e do alcance das medidas nela incluídas. Por seu lado, o n. ${ }^{\circ} 3$ do artigo $61 .^{\circ}$ da LBPSOTU determina que, sem prejuízo do apontado dever dos proprietários, "incumbe ao Estado, às regiões autónomas e às autarquias locais promover a reabilitação ou regeneração das áreas urbanas que dela careçam, programando ou conduzindo a realização das respetivas operações de reabilitação urbana ou concedendo apoios e outros incentivos financeiros e fiscais".

$\mathrm{O}$ artigo 5..$^{\circ}$ do RJRU estabelece também o dever de o Estado, as Regiões Autónomas e as autarquias locais promover as medidas necessárias à reabilitação das áreas urbanas que delas careçam e no artigo $6 .^{\circ}$ consagra, na mesma linha da LBPSOTU, o dever de os proprietários de edifícios ou frações assegurar a sua reabilitação, nomeadamente 
realizando todas as obras necessárias à manutenção ou reposição da sua segurança, salubridade e arranjo estético. Por seu lado, o Decreto-Lei n. ${ }^{\circ}$ 66/2019, de 21 de maio, que modificou algumas normas do RJUE e do RJRU, veio alterar as regras aplicáveis à intimação dos proprietários para a execução de obras de manutenção, reabilitação ou demolição e sua execução coerciva.

Também o PNPOT, revisto pela Lei n. ${ }^{\circ}$ 99/2019, de 5 de setembro, estabelece como objetivos promover a reabilitação urbana, qualificar o ambiente urbano e o espaço público, com o propósito de aumentar o conforto urbano com vista à proteção da saúde humana, da qualidade de vida das populações e da preservação dos ecossistemas, de criar de espaços públicos mais integrados, com maior identidade cultural e ambientalmente mais sustentáveis, reforçando a inclusão de pessoas com mobilidade reduzida ou outras incapacidades e de ampliar a área de espaço público e de espaços verdes por habitante.

É sobretudo no plano de pormenor de reabilitação urbana, considerado pelos artigos $103 .^{\circ}$ e $105 .^{\circ}$ do RJIGT como uma modalidade específica de plano de pormenor, que encontramos o ponto de interseção mais visível entre o planeamento urbanístico e a reabilitação urbana. De acordo com o artigo $105 .^{\circ}$, n. $^{\circ}$ 1, do RJIGT, o plano de pormenor de reabilitação urbana abrange solo urbano correspondente à totalidade ou a parte de um centro histórico delimitado em plano diretor ou plano de urbanização eficaz ou a uma área de reabilitação urbana constituída nos termos da lei. O conteúdo e as finalidades do plano de pormenor de reabilitação urbana são definidos nos artigos $21 .^{\circ}$ a $28 .^{\circ}$ do mencionado regime jurídico da reabilitação urbana.

Não pretendemos, neste local, analisar o regime jurídico da reabilitação urbana, ${ }^{38 / 39}$ mas tão-só vincar alguns dos seus objetivos, condensados no artigo $3 .^{\circ}$ do RJRU. De entre eles, selecionámos os seguintes: assegurar a reabilitação dos edifícios que se encontram degradados ou funcionalmente inadequados; reabilitar tecidos urbanos degradados ou em degradação; melhorar as condições de habitabilidade e de funcionalidade do parque imobiliário urbano e dos espaços não edificados; modernizar as infraestruturas urbanas; promover a sustentabilidade ambiental, cultural, social e económica dos

38 Sobre esta matéria, Alves Correia, F. (2014b, p. 253-276); Oliveira, Lopes e Alves (2011); Oliveira (2011) e Alves Correia, J. (2010).

39 Um dos aspetos mais importantes do regime da reabilitação urbana prende-se com os instrumentos financeiros necessários para a sua operacionalização e concretização. Neste contexto, assume relevância a Resolução do Conselho de Ministros n. ${ }^{\circ}$ 48/2016, de 1 de setembro, que criou o Fundo Nacional de Reabilitação do Edificado (FNRE), o qual se apresenta como um fundo especial de investimento imobiliário orientado para o desenvolvimento e a concretização de projetos de reabilitação de imóveis e para a promoção do arrendamento, tendo em vista a regeneração urbana e o repovoamento dos centros urbanos e é estruturado e regulado pelas leis aplicáveis a fundos de investimento imobiliário, com a possibilidade de recorrer, em situação de igualdade, aos programas e aos instrumentos financeiros disponibilizados pelo Estado e pelas demais entidades públicas para fins de reabilitação urbana e de arrendamento habitacional. 
espaços urbanos; fomentar a revitalização urbana, orientada por objetivos estratégicos de desenvolvimento urbano, em que as ações de natureza material são concebidas de forma integrada e ativamente combinadas na sua execução com intervenções de natureza social e económica; assegurar a integração funcional e a diversidade económica e sociocultural nos tecidos urbanos existentes; requalificar os espaços verdes, os espaços urbanos e os equipamentos de utilização coletiva; qualificar e integrar as áreas urbanas especialmente vulneráveis, promovendo a inclusão social e a coesão territorial; assegurar a igualdade de oportunidades dos cidadãos no acesso às infraestruturas, equipamentos, serviços e funções urbanas; desenvolver novas soluções de acesso a uma habitação condigna; e recuperar espaços urbanos funcionalmente obsoletos, promovendo o seu potencial para atrair funções urbanas inovadoras e competitivas.

$\mathrm{O}$ aumento exponencial do turismo a que se vinha assistindo nos últimos anos, antes da crise da pandemia da doença da COVID-19, bem como o grande volume de investimento em "estabelecimentos de alojamento local", entendidos como "aqueles que prestam serviços de alojamento temporário, nomeadamente a turistas, mediante remuneração", 40 impulsionaram a reabilitação urbana de muitos edifícios, sobretudo nos centros históricos das cidades de Lisboa e do Porto. Os efeitos sociais, altamente negativos, da gentrificação de muitos bairros históricos e consequente "expulsão" de vários antigos moradores não demoraram a fazer-se sentir. Pensa-se, no entanto, que a drástica diminuição do turismo em consequência da crise da pandemia da doença da COVID-19 fará libertar uma parte dos "estabelecimentos de alojamento local" para o mercado de arrendamento habitacional, minorando, desse modo, os efeitos negativos da gentrificação de muitos bairros históricos das cidades de Lisboa e do Porto.

\section{Um planeamento urbanístico fomentador da segurança urbana}

A CRP consagra, desde a sua versão originária, no artigo $27 .^{\circ}$, n. $^{\circ} 1$, o direito à liberdade e o direito à segurança como dois direitos fundamentais dos cidadãos, enquadrando-os nos direitos, liberdades e garantias pessoais. Trata-se de dois direitos que, embora distintos, estão intimamente ligados desde a sua formulação nas primeiras constituições liberais.

$\mathrm{O}$ direito à liberdade significa "o direito à liberdade física, à liberdade de movimentos, ou seja, o direito de não ser detido, aprisionado, ou de qualquer modo fisicamente confinado a um determinado espaço, ou impedido de se movimentar" e o

40 O regime jurídico de exploração dos "estabelecimentos de alojamento local" consta do Decreto-Lei n. ${ }^{\circ}$ 128/2014, de 29 de agosto, alterado pelo Decreto-Lei n. ${ }^{\circ} 63 / 2015$, de 23 de abril, e pela Lei n. ${ }^{\circ} 62 / 2018$, de 22 de agosto (que, além disso, republica em anexo o mencionado regime). 
direito à segurança significa essencialmente "garantia de exercício seguro e tranquilo dos direitos, liberto de ameaças ou agressões". ${ }^{41}$

É consabido que a garantia da segurança e ordem públicas desempenha uma função essencial de proteção e garantia dos direitos fundamentais, uma vez que só numa situação de segurança e ordem públicas podem os cidadãos exercer efetivamente os seus direitos fundamentais, em particular a sua liberdade. ${ }^{42}$ Quer isto dizer que "sem segurança não há liberdade", mas também, num Estado de Direito, que "sem liberdade não há segurança”. (BRITO, 2009, p. 317-318).

O planeamento urbanístico pode desempenhar uma função importante de fomento da segurança urbana. Ela passa, em primeiro lugar, pela identificação pelos programas e planos territoriais das "áreas afetas à defesa nacional, à segurança e à proteção civil" [artigo $10^{\circ}$, alínea a), do RJIGT]. Passa, em segundo lugar, pela definição pelo legislador de diretivas de ponderação, determinando, a propósito da ponderação entre interesses públicos divergentes coenvolvidos na ocupação, uso e transformação dos solos realizada pelos planos, pela prioridade dos interesses respeitantes à defesa nacional, à segurança, à saúde pública, à proteção civil e à prevenção e minimização de riscos sobre os demais interesses públicos (artigo 9..$^{\circ}$, n. ${ }^{\circ}$ 2, do RJIGT). Passa, em terceiro lugar, pela identificação nos programas e nos planos territoriais do "conjunto dos equipamentos, infraestruturas e sistemas que asseguram a segurança, a proteção civil e a prevenção e minimização de riscos" (artigo 11. ${ }^{\circ}$, n. ${ }^{\circ}$ 2, do RJIGT).

E passa, finalmente, pela incorporação das preocupações de segurança no planeamento e no desenho urbanos. Desenvolvendo um pouco mais esta ideia, é facilmente percetível que cidades com ruas, avenidas e praças largas, com traçado linear, sem obstáculos visuais, sem interrupção de iluminação, com altura de vegetação controlada e com muito espaço público são cidades mais seguras e que criam uma sensação de segurança aos cidadãos. É esta uma das razões, ao lado da existência de equipamentos adequados, que está na base da escolha frequente do Parque das Nações, em Lisboa, para receber cimeiras de Chefes de Estado e de Governo, provas desportivas, congressos e espetáculos musicais. E as forças de segurança valorizam sobremaneira estes aspetos. Razões de segurança também terão estado na base, ao lado de outras, da decisão política (adotada em 1956) da construção e da mudança da capital do Brasil do Rio de Janeiro para

${ }_{41}$ Canotilho (2007, p. 478-479), e os Acórdãos do Tribunal Constitucional Português n. ${ }^{\text {os }} 479 / 1994,436 / 2000$ e $471 / 2001$.

42 Friauf (1984, p. 187). Como sublinha Morand-Deviller (2015, p. 525-526), citando a jurisprudência do Conselho Constitucional francês, a segurança, como uma das componentes da ordem pública, é um meio de garantia dos direitos fundamentais e, simultaneamente, uma condicionante ao exercício das liberdades individuais e coletivas. 
Brasília. Esta é, pode dizer-se, neste sentido, um caso exemplar, tanto pelo seu desenho como pela sua localização.

Nas últimas três décadas do século passado, vários autores, entre os quais Timothy D. Crowe, C. Ray Jeffery e Oscar Newman, desenvolveram, na linha de Jane Jacobs e Elisabeth Wood, uma abordagem metodológica que prevê a introdução de princípios no desenho urbano e na utilização do espaço público com o intuito de tornar as cidades mais seguras, a qual é conhecida pela sigla CPTDE (Crime Prevention Through Environmental Design). Esta expressão foi cunhada em 1971 por C. Ray Jeffery, mas o autor que mais contribuiu para o desenvolvimento do conceito de CPTED foi o criminologista Timothy D. Crowe, na sua obra com o mesmo título, de 1991. Nascida nos Estados Unidos da América, a CPTED expandiu-se rapidamente para outros países, tais como o Canadá, o Reino Unido, a Holanda, o Japão e a Austrália. A mesma baseiase numa ideia simples: a de que o crime resulta em boa parte das oportunidades que são proporcionadas pelo ambiente físico, pelo que é possível alterar o ambiente físico de modo a que o crime tenha menos probabilidades de ocorrer. (CROWE, 2013, p. 3-14).

Notas essenciais daquela abordagem são a conceção e a definição dos espaços urbanos de acordo com as suas finalidades, de modo a que eles sejam portadores de definições sociais, culturais, legais ou físicas que incentivem os seus utilizadores à adoção de comportamentos adequados e contextualizados com o meio e contribuam para que os indivíduos melhorem a sua perceção de segurança no meio urbano. A CPTED baseia-se em três estratégias sobrepostas, a serem observadas no planeamento territorial e no desenho urbano: a do controlo de acesso natural [podendo as estratégias de controlo de acesso natural ser “organizadas” (v.g., serviços de segurança), "mecânicas” (v.g., chaves) e "naturais" (v.g., definição espacial)]; a da vigilância natural [sendo as estratégias de vigilância natural classificadas em "organizadas" (v.g., patrulhas policiais), "mecânicas" (v.g., iluminação) e "naturais" (v.g., janelas)]; e a do reforço territorial, no sentido de que o desenho físico pode criar ou ampliar a esfera de influência, em termos tais que os utilizadores desenvolvam um sentido de relação de propriedade - um sentido de influência territorial - e os potenciais criminosos percebam essa influência territorial. (CROWE, 2013, p. 27-29 e 284-292).

Para a melhoria da perceção da segurança no espaço urbano, muito contribuem: a orientação e a leitura do espaço pelas pessoas, isto é, a capacidade de as pessoas se orientarem no espaço, preverem as potenciais alterações e dinâmicas e perceberem e encontrarem o percurso para o ponto onde querem chegar; a possibilidade de "ver e ser visto", os conhecidos "olhos da rua" (Jane Jacobs), ou seja, a possibilidade de os indivíduos observarem integralmente o espaço público que utilizam, em termos de serem capazes de preverem a aproximação de outros indivíduos ou objetos e, deste modo, reduzirem a sua perceção de vulnerabilidade face ao desconhecido (o que implica, entre 
o mais, que, no espaço público, haja uma grande permeabilidade visual e uma iluminação adequada, que existam janelas envidraçadas nas fachadas dos prédios habitados, que permitam aos moradores e utilizadores dos espaços privados uma natural vigilância dos espaços públicos, e que se verifique uma combinação adequada e complementar de usos e atividades que levem diferentes grupos e pessoas a permanecer, a circular e a usufruir do espaço público em diferentes momentos do dia); a perceção do estatuto dos espaços, qual seja a perceção clara da natureza estatutária e funcional do espaço e a existência de fronteiras nítidas entre espaços públicos, privados e semiprivados e entre diferentes funções do espaço incompatíveis entre si, de modo a reduzir eventuais conflitos e facilitar a "apropriação" legítima dos espaços; a dotação da cidade de espaços públicos, isto é, a oferta variada e razoável de espaço público adequado às diversas necessidades e modos de fruição dos cidadãos, enquanto elementos essenciais para a satisfação e o envolvimento sócio afetivo dos habitantes com a sua comunidade e para o usufruto por todos da dimensão da cidade, com particular destaque para os espaços coletivos agregadores da comunidade local, que crianças, jovens, adultos e idosos, homens e mulheres, de diferentes estratos sociais, usufruem com idêntico grau de segurança e confiança; e a manutenção e gestão do espaço público, ou seja, a organização e limpeza do espaço público, a manutenção dos equipamentos urbanos e a conservação do edificado privado, que conformam uma imagem do espaço urbano imediatamente percecionada como mais segura do que espaços desordenados e aparentemente negligenciados. ${ }^{43}$

Vários estudos realizados e publicados pelo Departamento de Justiça dos Estados Unidos da América demonstraram que a aplicação dos conceitos da teoria da Crime Prevention Through Environmental Design reduziram a incidência do crime e do medo do crime, tendo sido alcançados resultados significativos em diversos lugares, incluindo áreas residenciais, centros comerciais, estações ferroviárias e rodoviárias e parques de estacionamento. Tudo isto revela que o modo como planeamos e construímos as nossas cidades tem uma grande influência na diminuição do crime e no aumento da segurança dos cidadãos e na perceção que eles têm do gozo deste seu direito fundamental.

9. Um planeamento urbanístico incentivador da proteção e valorização do património cultural

Os programas e os planos territoriais são também importantes instrumentos de proteção e valorização do património cultural, entendido, à luz da CRP (artigo 78. ${ }^{\circ}$ ) e da lei [Lei de Bases da Política de Proteção e Valorização do Património Cultural (LPC)

43 Sobre esta problemática, Alves Correia, F. (2016, p. 426-429). 
- Lei n. ${ }^{\circ}$ 107/2001, de 8 de setembro], simultaneamente como uma tarefa fundamental do Estado e como um direito à respetiva fruição universal pelos cidadãos.

$\mathrm{O}$ artigo $2 .^{\circ}$, alínea $h$ ), da LBPSOTU enuncia, desde logo, como um dos fins da política pública de solos, de ordenamento do território e de urbanismo "promover a defesa, fruição e valorização do património natural, cultural e paisagístico" ${ }^{44} \mathrm{Na}$ mesma senda, o artigo $10{ }^{\circ}$, alínea $g$ ), do RJIGT estabelece que os programas e os planos territoriais identificam "o património arquitetónico, arqueológico e paisagístico", de modo a que o interesse público com eles relacionado seja ponderado com os restantes interesses públicos e privados coenvolvidos na ocupação, uso e transformação do solo. E o artigo $17 .^{\circ}$ do mesmo diploma, com a epígrafe "património arquitetónico, arqueológico e paisagístico", determina, no seu n. ${ }^{\circ} 1$, que "os vestígios arqueológicos, bem como os elementos e conjuntos construídos, que representam testemunhos da história da ocupação e do uso do território e assumem interesse relevante para a memória e a identidade das comunidades, são identificados nos programas e nos planos territoriais"; prescreve, no seu n. ${ }^{\circ}$, que "os programas e os planos territoriais estabelecem as medidas indispensáveis

44 Este preceito suscita a questão da identidade ou autonomia entre o património cultural e o património natural. Trata-se de um problema que tem sido colocado, com acuidade, no direito português. Ele tem dado origem a um vivo debate doutrinal, que, contudo, não pode alhear-se daqueles que são os dados jurídicopositivos. A evolução sentida no direito internacional, especialmente a partir da convenção da UNESCO de 1972 sobre a proteção do património mundial cultural e natural, vai claramente no sentido da implementação de um conceito amplo de património cultural. A assimilação ou identidade entre bens culturais e ambientais tem, portanto, subjacente um conceito de património cultural em sentido amplo e a estreita ligação entre o direito do ambiente e o direito do património cultural pode justificar uma visão unitária.

Contudo, a orientação imprimida pelo ordenamento jurídico português às relações que intercedem entre património cultural e património natural, ambiental ou paisagístico não se revela de sentido unitário. Por um lado, ao nível constitucional, observa-se uma distinção entre a tutela do património ambiental (artigo 66. ${ }^{\circ}$ da CRP) e a tutela do património cultural (artigo $78 .^{\circ}$ da CRP), que, desde logo, parece rejeitar uma solução unitária. Por outro lado, a referência conjunta, no artigo $165 .^{\circ}, \mathrm{n}^{\circ}$ 1, alínea $g$ ), da CRP, a propósito da reserva relativa de competência legislativa da Assembleia da República, ao património cultural e ambiental (“às bases do sistema de proteção da natureza, do equilíbrio ecológico e do património cultural”) nunca constituiu um obstáculo à existência de duas Leis de Bases relativamente aos domínios em causa, uma tendo por seu objeto os princípios reitores da política do ambiente (Lei n. ${ }^{\circ}$ 19/2014, de 14 de abril) e outra tendo por referência, precisamente, a proteção e valorização do património cultural (LPC). Ora, isto significa, pelo menos ao nível do direito ordinário, que estamos em face de realidades distintas e credoras de uma disciplina tendencialmente diferenciada. Por outras palavras, no direito português, o legislador não encara de maneira unitária o património cultural e natural, tendo editado duas Leis de Bases relativamente aos domínios em causa. Por essa razão, no ordenamento jurídico português, persistem sistemas normativos e organizatórios específicos e, nessa medida, perfeitamente individualizados, para o património cultural e o património natural, implicando que as tarefas de execução das políticas públicas relativas a bens culturais e a bens ambientais sejam reservadas a departamentos ministeriais e a órgãos públicos distintos. Enquanto o património cultural está sob tutela do Ministério da Cultura, o património natural está sob tutela do Ministério do Ambiente, intervindo nessa matéria, de forma destacada, a Agência Portuguesa do Ambiente e o Instituto da Conservação da Natureza e da Biodiversidade.

Tudo isto concorre para a afirmação da autonomia entre património cultural e património natural sem menoscabo da sua relação de interdependência. Sobre as relações entre património cultural e património natural, Alves Correia, F. (1996, p. 393-418) e Nabais (2001, p. 188-192). 
à proteção e à valorização do património arquitetónico, arqueológico e paisagístico, acautelando o uso dos espaços envolventes"; e preceitua, no seu n. ${ }^{\circ} 3$, que "no quadro definido por lei e pelos programas e planos territoriais, cuja eficácia condicione o respetivo conteúdo, os planos intermunicipais e municipais estabelecem os parâmetros urbanísticos aplicáveis e a delimitação de zonas de proteção".

É, porém, no âmbito dos planos de pormenor que se verifica uma forte confluência entre o planeamento urbanístico e a proteção e valorização do património cultural. Com efeito, a LPC contempla, para além do plano de ordenamento de parque arqueológico, que é, atualmente, considerado como um programa especial de ordenamento do território (artigo 42. ${ }^{\circ}$, n. ${ }^{\circ}$, do RJIGT), os planos de pormenor de salvaguarda. Planos estes que o RJIGT qualifica como modalidade especifica de planos de pormenor e cujo regime jurídico é remetido por este mesmo diploma para a LPC (artigos $103 .^{\circ}$ e $106 .^{\circ}$ do RJIGT) e para a legislação complementar, isto é, para o Decreto-Lei n. ${ }^{\circ} 309 / 2009$, de 23 de outubro, alterado pelos Decretos-Leis n. ${ }^{\text {os }} 115 / 2011$, de 5 de dezembro, e 265/2012, de 28 de dezembro.

Relativamente a estes últimos, o artigo $53 .^{\circ}$, n. ${ }^{\circ} 1$, da LPC, determina que o ato que decrete a classificação de monumentos, conjuntos ou sítios, ou em vias de classificação, obriga o município, em parceria com os serviços da administração central ou regional autónoma responsáveis pelo património cultural, ao estabelecimento de um plano de pormenor de salvaguarda para a área a proteger. Por seu lado, o artigo $64 .^{\circ}$ do

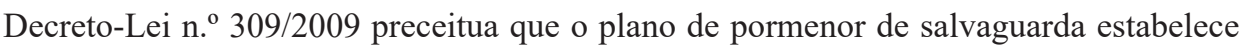
as orientações estratégicas de atuação e as regras de uso e ocupação do solo e edifícios necessárias à preservação e valorização do património cultural existente na sua área de intervenção, desenvolvendo as restrições e os efeitos estabelecidos pela classificação do bem imóvel e pela zona especial de proteção, podendo o mesmo, de acordo com o artigo $65 .^{\circ}$ do referido diploma legal, abranger o solo rural e o solo urbano correspondente à totalidade ou parte de um bem imóvel classificado e respetiva zona de proteção.

Relativamente aos planos de pormenor de salvaguarda, a doutrina vem discutindo a questão de saber a que tipo de instrumento de gestão territorial referido no RJIGT se devem os mesmos reconduzir. Se se atentar na respetiva designação e em alguns aspetos do seu regime jurídico (v.g., os seus efeitos jurídicos diretos e imediatos em relação aos particulares e a dispensa de parecer prévio das entidades administrativas competentes em matéria de património cultural), seremos levados a considerá-los como planos de pormenor, isto é, como uma espécie de planos municipais de ordenamento do território. Foi, aliás, nesta linha que seguiu o legislador. Com efeito, os mencionados preceitos do RJIGT consideram o plano de pormenor de salvaguarda como uma modalidade específica de plano de pormenor, cujo conteúdo é definido no citado Decreto-Lei n. ${ }^{o}$ 309/2009. Todavia, se colocarmos o acento tónico na natureza dos bens jurídicos em questão, que 
extravasam em larga medida o âmbito municipal, bem como no facto de estes planos deverem ser elaborados pelos municípios em parceria com os serviços da administração central ou regional responsável pelo património cultural, seremos transportados para um nível de planeamento superior ao âmbito municipal, que, atendendo à atual configuração jurídica dos instrumentos de programação e de planeamento territorial, constante da LBPOTU e do RJIGT, não pode ser outro senão o de um plano (atualmente, programa) setorial. $^{45 / 46}$

10. Um planeamento urbanístico promotor da observância do princípio da igualdade

Os planos territoriais devem, por último, respeitar o princípio da igualdade, quer na dimensão de princípio da igualdade imanente ao plano, quer na de princípio da igualdade transcendente ao plano. Uma tal obrigação resulta do princípio constitucional da igualdade do cidadão, consagrado no artigo $13 .^{\circ}$ da CRP, o qual, enquanto princípio estruturante do Estado de direito democrático e do sistema constitucional global, vincula diretamente os poderes públicos, tenham eles competência legislativa, administrativa ou jurisdicional. E, no que concerne à atividade administrativa, a vinculação da Administração Pública ao princípio da igualdade está expressamente contemplada no artigo $266^{\circ}$, n. $^{\circ}$ 2, daquela Lei Fundamental. Com vista ao cumprimento deste quadro constitucional, o artigo 3..$^{\circ}$, alínea $f$ ), da LBPSOTU indica como um dos princípios gerais das políticas públicas e das atuações administrativas em matéria de solos, de ordenamento do território e de urbanismo a "equidade, assegurando a justa repartição dos benefícios e dos encargos decorrentes da aplicação dos programas e planos territoriais e dos instrumentos de política de solos".

A dimensão do princípio da igualdade imanente ao plano ou princípio da proibição do arbitrio (Willkürverbot) tem o sentido de que as disposições do plano não podem ser arbitrárias. O plano, enquanto instrumento simultâneo de criação e de aplicação do direito, não pode ser ilógico e as medidas que prescrevem um tratamento diferenciado dos proprietários do solo não podem ser irrazoáveis, antes têm de basear-se em fundamentos objetivos ou materiais bastantes. A violação deste princípio da igualdade imanente ao plano - o qual está envolvido na sua própria lógica interna de índole racional - teleológica - tem como consequência a invalidade das correspondentes disposições do plano, por ofensa direta ao preceito constitucional que consagra o princípio da igualdade.

45 Sobre esta problemática, Silva (2002, p. 80-81) e Alves Correia, F. (2008, p. 375-376).

46 Para mais desenvolvimentos sobre o regime jurídico da proteção e valorização do património cultural português, Nabais (2010); Alves Correia, F. e Azevedo (2017, p. 87-119); Alves Correia, F. e Alves Correia, J. (2019, p. 421-449). 
A dimensão do princípio da igualdade transcendente ao plano tem uma dupla incidência: como "princípio da igualdade perante os encargos públicos" e como "princípio da igualdade de «chances» ou de oportunidades urbanísticas".

O "princípio da igualdade perante os encargos públicos” expressa a ideia segundo a qual um indivíduo que, em comparação com os restantes cidadãos, suporta um sacrifício especial e grave ou anormal em benefício da comunidade deve ser, por efeito do princípio da igualdade, indemnizado por essa mesma comunidade. A sua aplicação, no âmbito dos planos diz respeito às denominadas expropriações do plano, isto é, àquelas disposições dos planos vinculativos dos particulares que traduzem modificações especiais e graves no direito de propriedade que não podem deixar de ser consideradas como "expropriativas" (expropriações de sacrificio ou substanciais) e, consequentemente, ser acompanhadas de indemnização. As expropriações do plano são expropriações de sacrifício ou expropriações em sentido substancial.

Por seu lado, o "princípio da igualdade de «chances» ou de oportunidades urbanísticas" reporta-se às medidas que definem formas e intensidades diferentes de utilização para as várias parcelas de terrenos, que não são consideradas como expropriações, e, consequentemente, não são acompanhadas da obrigação de indemnização, nos termos do artigo $62 .^{\circ}$, n. $^{\circ}$ 2, da CRP. Tais medidas não deixam, porém, de significar um tratamento desigual dos diferentes proprietários e, por isso, também aí o princípio da igualdade adquire relevância.

As dimensões anteriormente referidas de relevância do princípio da igualdade no planeamento urbanístico suscitam respostas diferenciadas do ordenamento jurídico.

Assim, no caso de violação do princípio da igualdade imanente ao plano ou princípio da proibição do arbítrio, os particulares desfavorecidos pelas correspondentes disposições dos planos têm o direito de impugnar judicialmente a sua validade. $\mathrm{O}$ âmbito de aplicação daquele princípio é, no entanto, bastante reduzido, dado que é preciso demonstrar que as prescrições do plano são totalmente ilógicas, tendo em conta os fins do plano, irrazoáveis, objetivamente infundadas e arbitrárias.

Na hipótese de violação do princípio da igualdade transcendente ao plano, na vertente de violação do princípio da igualdade perante os encargos públicos, tem o particular direito a uma indemnização.

Por fim, nos casos de violação do princípio da igualdade transcendente ao plano, na modalidade de violação do princípio da igualdade de «chances» ou de oportunidades urbanísticas, há uma imposição ao legislador para consagrar mecanismos ou instrumentos que visem corrigir as desigualdades de tratamento entre os proprietários do solo. A sua força jurídica traduz-se numa diretiva ao legislador ou numa imposição 
legiferante, para que lance medidas de perequação dos benefícios e encargos decorrentes do plano entre os proprietários do solo por ele abrangidos.

Não é este o local adequado para desenvolvermos a problemática das relações entre os planos territoriais e o princípio da igualdade. ${ }^{47}$ Acrescentaremos tão-só, umas breves notas.

Quanto ao princípio da igualdade de «chances» ou de oportunidades urbanísticas, os artigos $64 .^{\circ}$ a $66 .^{\circ}$ da LBPSOTU e os artigos $176 .^{\circ}$ a $183 .^{\circ}$ do RJIGT consagraram o princípio da redistribuição equitativa de benefícios e encargos resultantes dos planos territoriais e definiram o respetivo regime jurídico, inspirandose profundamente no ordenamento jurídico urbanístico espanhol. É aquele um princípio mais amplo e mais ambicioso do que o princípio da perequação compensatória dos benefícios e encargos decorrentes dos planos municipais entre os proprietários dos solos, consagrado na legislação anterior, e cujo objetivo é garantir a igualdade de tratamento entre os proprietários do solo abrangidos por um mesmo plano territorial. Com aquele novo princípio pretende-se, além desta finalidade, fazer participar o conjunto dos cidadãos abrangidos por um plano territorial nas mais-valias gerais atribuídas por um tal instrumento de planeamento. No quadro de um novo figurino da redistribuição de benefícios e encargos, o artigo $66 .^{\circ}$ da LBPSOTU elenca três tipos de mecanismos de redistribuição de benefícios e encargos: afetação social de mais-valias gerais atribuídas pelos planos territoriais (a qual é devida pela reclassificação do solo como urbano e pela outorga de direitos de edificação e é destinada à compensação ambiental da transformação do solo e do aumento da carga edificatória), de acordo com os critérios neles definidos; distribuição dos benefícios e encargos decorrentes do plano territorial entre os proprietários fundiários (a denominada perequação intraplano); e contribuição com áreas para a implementação, instalação e renovação de infraestruturas, equipamentos, espaços verdes e outros espaços de utilização coletiva (através das cedências urbanísticas).

No tocante ao princípio da igualdade perante os encargos públicos, o artigo $17 .^{\circ}$ da LBPSOTU consagra o princípio segundo o qual o sacrifício de direitos preexistentes e juridicamente consolidados (n. $\left.{ }^{\circ} 1\right)$ ou qualquer sacrifício imposto aos proprietários do solo que tenha um efeito equivalente a uma expropriação (n. ${ }^{\circ} 3$ ) devem ser acompanhados de compensação ou de indemnização, conforme os casos. No que respeita aos sacrifícios do primeiro tipo, adianta o n. ${ }^{\circ} 1$ daquele preceito que eles só podem ter lugar nos casos expressamente previstos na lei ou nos planos territoriais aplicáveis e mediante o pagamento de compensação (no caso da existência de mecanismos adequados de perequação de benefícios e encargos resultantes dos planos territoriais) ou indemnização. Por sua vez,

47 Sobre este tema, Alves Correia, F. (2001, p. 393 et seq., 2008, p.729-795, 2018a, p. 9-25, 2018b, p. 521-538, 2019, p. 21-54). 
o n. ${ }^{\circ} 2$ do artigo $17 .^{\circ}$ estatui que a referida compensação ou indemnização é prevista, obrigatoriamente e de forma expressa, no plano territorial de âmbito intermunicipal ou municipal que fundamenta a imposição do sacrifício, nomeadamente através da definição de mecanismos de perequação deles resultantes. No que respeita ao segundo tipo de expropriações de sacrifício de índole urbanística, o n. 3 do artigo $17 .^{\circ}$ refere que são acompanhadas de indemnização, tendo em conta a inadequação, por via de regra, dos mecanismos de perequação para a compensação dos mesmos.

No que concerne ao regime da indemnização das expropriações do plano, foi objetivo primordial do legislador clarificar muitas das dúvidas suscitadas pela disciplina jurídica antecedente. Tanto a LBPSOTU como o RJIGT mantêm-se fiéis ao princípio do caráter não indemnizatório dos planos municipais e intermunicipais de ordenamento do território, dado que estes são considerados como instrumentos que definem o "conteúdo e limites do direito de propriedade do solo", pelo que as proibições, limitações e condicionamentos às possibilidades de utilização do solo que deles decorrem não têm, por via de regra, caráter expropriativo, não dando, por isso, origem a qualquer indemnização. Noutra perspetiva, entende-se, de um modo geral, que aqueles planos não retiram faculdades de uso, ocupação e transformação do solo para fins de urbanização e de edificação, antes atribuem positivamente tais faculdades. E mantêm-se fiéis, outrossim, ao princípio da subsidiariedade da indemnização em relação aos mecanismos de perequação dos benefícios e encargos resultantes dos planos (artigo 171. ${ }^{\circ}$, n. ${ }^{\text {os }} 1$ e 8 , do RJIGT).

Não obstante a referida natureza das disposições dos planos urbanísticos, existem certas disposições que produzem danos especiais (singulares) e graves (anormais) no direito de propriedade do solo ou noutro direito real limitado e que, por isso, devem ser consideradas como tendo um caráter expropriativo, as quais configuram verdadeiras expropriações do plano, que, no caso de impossibilidade da sua compensação através dos mecanismos de perequação, devem ser acompanhadas de indemnização, sob pena de serem violados os princípios constitucionais da igualdade dos cidadãos perante os encargos públicos, do Estado de direito e da justa indemnização por expropriação. Casos estes que são excecionais. Por isso, o legislador procurou tipificar esses casos excecionais, evitando, sempre que possível, a utilização de cláusulas de contornos imprecisos, seguindo os trilhos rasgados pelos ordenamentos jurídicos urbanísticos alemão e espanhol.

$\mathrm{O}$ preceito mais importante do RJIGT relativo à indemnização das expropriações do plano é o artigo 171. ${ }^{\circ}$. Este tipifica os casos de expropriações do plano, que devem ser acompanhadas de indemnização de acordo com o anteriormente indicado princípio da subsidiariedade da indemnização em relação aos mecanismos de perequação, utilizando uma técnica legislativa mais rigorosa do que a do artigo $143 .^{\circ}$ do anterior RJIGT. 
III. Breve nota conclusiva

$\mathrm{O}$ facto de o presente texto ter sido revisto e atualizado à data de 31 de julho de 2020 impõe-nos que façamos uma referência, ainda que em termos necessariamente breves, às consequências, ainda muito imprecisas, sobre o direito do urbanismo, e em particular sobre o planeamento urbanístico, da pandemia da doença da COVID-19.

As ondas de choque da pandemia da doença da COVID-19 serão gigantescas. Fala-se no início de uma nova "era", cujas repercussões políticas, económicas e sociais ainda não são facilmente identificáveis. Especificamente quanto ao direito do urbanismo, a primeira questão que queremos suscitar é a de saber se aquela pandemia não implicou, em certa medida, um regresso ao século XIX, no qual o objetivo essencial da legislação urbanística era resolver os problemas sanitários e de higiene decorrentes da localização, adensamento e extensão dos bairros operários e de lutar contra as grandes epidemias, entre as quais a de cólera, com a consequente queda vertiginosa da média de vida dos operários que residiam nos referidos bairros. ${ }^{48}$ Tudo isto apontaria para o ressurgimento de um "urbanismo sanitário", fortemente influenciado pela prevenção e mitigação de pandemias, colocando em causa a conceção da cidade compacta e densa.

Mas independentemente deste recrudescimento da importância das questões sanitárias na reconfiguração do direito do urbanismo, é seguro que a obrigação de "permanecer em casa" ("stay at home"), a obrigação de teletrabalho ou outras formas de trabalho no domicílio e, bem assim, as modalidades de ensino não presencial, através de plataformas digitais, impostas pelos governos, pelas entidades patronais e pelas escolas, implicaram uma revalorização da habitação, no contexto do direito do urbanismo. A habitação deixou de ser o local onde apenas se "dorme", para ser o local onde se "vive", se trabalha, se ensina e se estuda e se permanece confinado por muito tempo.

No contexto da pandemia da doença COVID-19 ganhou também relevo a necessidade de promover a melhoria das condições sanitárias e das condições de conforto das habitações, das condições ambientais, da qualidade de vida das comunidades locais e da coesão social. Lembre-se que, durante o "estado de emergência", as pessoas apenas podiam sair da residência, para trabalhar, ir à farmácia ou ao supermercado, e para fazer algum exercício físico na proximidade das suas habitações. Tudo isto implicou uma atenção especial à criação de espaços públicos seguros, inclusivos e saudáveis, à instalação ou melhoria de equipamentos desportivos, à melhoria de acessibilidades externas às habitações, à promoção de um desenho e gestão participados dos mesmos e à promoção da proteção ambiental, sobretudo através do aumento de áreas verdes e

48 Sobre este tema, Alves Correia, F. (2008, p. 190-196). 
de áreas bem arejadas e impregnadas de luz e de sol. Tornou-se, assim, premente uma revitalização da reabilitação urbana e a criação de Bairros Saudáveis, com a finalidade de dinamizar parcerias e intervenções locais de promoção da saúde e da qualidade de vida das comunidades territoriais (veja-se o Programa Bairros Saudáveis, aprovado pela Resolução do Conselho de Ministros n. ${ }^{o}$ 52-A/2020, de 1 de julho).

Outro impacto da pandemia da doença COVID-19 no direito do urbanismo é a ampliação do recurso ao denominado "urbanismo tático", isto é, a um urbanismo mais flexível no planeamento urbanístico e na gestão urbanística, que privilegia iniciativas de pequena escala, rápidas e de fácil execução nos espaços urbanos, de que são exemplo as pinturas (de vias e de ruas, de muros, de equipamentos, etc.), a disponibilização de mobiliário urbano móvel, como forma de promover mobilidade, acessibilidade, segurança, espaços de lazer e cultura e de promover o "direito à cidade", o aproveitamento de espaços públicos para esplanadas de cafés e restaurantes, de modo a permitir o distanciamento físico entre as pessoas, ou o encerramento temporário de avenidas e de ruas para permitir a circulação e a prática de atividade desportiva, em condições de segurança. ${ }^{49}$

Não querendo deixar de fazer uma curtíssima referência às consequências ambientais da pandemia, neste caso benéficas, é sabido que a diminuição drástica, durante o período do "lock down", da deslocação das pessoas, a ampliação do "teletrabalho" a partir das habitações e as modalidades de ensino em casa tiveram um efeito benéfico na redução das emissões de $\mathrm{CO}_{2}$. Aproveitando este impulso, há que reforçar a aposta nos modos de transporte suave, designadamente através do estímulo ao uso da bicicleta e do reforço da mobilidade elétrica. Mas também no domínio da mobilidade urbana, podemos descortinar efeitos nefastos da pandemia. Se antes da pandemia, um dos grandes objetivos da política de transportes e da política ambiental era incentivar a utilização dos transportes coletivos nas deslocações urbanas e interurbanas (melhorando o transporte coletivo e implementando medidas dissuasoras de utilização do automóvel individual) e estimular o recurso ao car-sharing, bike-sharing e car pooling, teme-se que os receios do contágio pelo novo Coronavírus em transportes públicos sobrelotados e em viaturas partilhadas faça recrudescer o recurso ao transporte em carro individual.

Coimbra, agosto de 2020.

$49 \quad$ Sobre o tema, Brenner (2015). 


\section{Referências}

ALVES CORREIA, Fernando. A nova lei de bases gerais da política pública de solos, de ordenamento do território e do urbanismo: alguns princípios fundamentais. Revista CEDOUA, Coimbra, ano 17, n. 34, p. 9-21, 2014a.

ALVES CORREIA, Fernando. Apresentação dos temas. In: SILVA, Susana Tavares da (coord.). Desafios actuais em matéria de sustentabilidade ambiental e energética. Coimbra: Universidade de Coimbra, 2015. p. 235-240.

ALVES CORREIA, Fernando. Direito do ordenamento do território e direito do urbanismo Europeu: apontamentos para uma reflexão. In: ESTUDOS em Homenagem a António Barbosa de Melo. Coimbra: Almedina, 2013. p. 209-256. p. 220-228.

ALVES CORREIA, Fernando. Direito fundamental à segurança e direito do urbanismo: um olhar Luso-Brasileiro. In: SOUSA, Marcelo Rebelo de; PINTO, Eduardo Vera-Cruz (coord.). Liber amicorum Fausto de Quadros. Coimbra: Almedina, 2016. v. 1. p. 415-435. p. 426-429.

ALVES CORREIA, Fernando. Evolução do direito do urbanismo em Portugal de 2012 a 2017. Revista do CEDOUA, Coimbra, ano 21, n. 41, p. 9-25, jan./jun. 2018a.

ALVES CORREIA, Fernando. L'évolution de la législation d'urbanisme du Portugal de 2012 à 2017. In: DROIT de l'aménagement de l'urbanisme et de l'habitat. Paris: Le Moniteur, 2018b. p. 521-538.

ALVES CORREIA, Fernando. Linhas gerais do ordenamento e gestão da zona costeira em Portugal. Revista de Legislação e de Jurisprudência, Coimbra, ano 138, n. 3.956, p. 252-267, maio/jun. 2009.

ALVES CORREIA, Fernando. Manual de direito do urbanismo. 4. ed. Coimbra: Almedina, 2008. v. 1. p. 346-602.

ALVES CORREIA, Fernando. O plano urbanístico e o princípio da igualdade. Coimbra: Almedina, 2001. p. 393 et seq.

ALVES CORREIA, Fernando. Portugal: rapport national. In: RENDERS, David et al. Le renouvellement urbain en Europe. Paris: Gridauh, 2014b. p. 253-276. (Les Cahiers du GRIDAUH, n. $\left.{ }^{\circ} 27\right)$.

ALVES CORREIA, Fernando. Propriedade de bens culturais: restrições de utilidade pública e servidões administrativas. In: MIRANDA, Jorge; CLARO, João Martins; ALMEIDA, Marta Tavares de. Direito do património cultural. Lisboa: Instituto Nacional de Administração, 1996. p. 393-418.

ALVES CORREIA, Fernando. Tendências actuais do direito do urbanismo Português e Europeu e o "Estado da Arte" do ordenamento jurídico urbanístico da região administrativa especial de Macau. Revista de Legislação e de Jurisprudência, Coimbra, ano 139, n. 3.963, jan./fev. 2010. p. 333-335. 
ALVES CORREIA, Fernando. Últimos desenvolvimentos do direito de indemnização dos planos em Portugal. Revista de Derecho Urbanistico y Medio Ambiente, Madrid, ns. 330-331, p. 21-54, jun./jul./ago. 2019.

ALVES CORREIA, Fernando; ALVES CORREIA, Jorge. Le droit du patrimoine culturel au Portugal (Rapport Portugais). In: RENDERS, David; MORAND-DEVILLER, Jacqueline; GIFREU FONT, Judith (coord.). Patrimoine architectural, sites et paysages saisis par le droit de l'urbanisme. Bruxelles: Bruylant, 2019. p. 421-449.

ALVES CORREIA, Fernando; AZEVEDO, Bernardo de Mascarenhas Almeida. O regime jurídico de proteção e valorização do património cultural em Portugal. In: LÓPEZ RAMÓN, Fernando (coord.). El patrimonio cultural en Europa y Latinoamérica. Madrid: INAP, 2017. p. 87-119.

ALVES CORREIA, Fernando; MONIZ, Ana Raquel Gonçalves. Consideraciones sobre la promoción del derecho a la vivienda en Portugal. In: LÓPEZ RAMÓN, Fernando (coord.). Construyendo el derecho a la vivienda. Madrid, Barcelona, Buenos Aires: Marcial Pons, 2010a. p. 137-164.

ALVES CORREIA, Fernando; MONIZ, Ana Raquel Gonçalves. Mobilité, urbanisme et environnement: le cas Portugais. In: RENDERS, Davi; MORAND-DEVILLER, Jacqueline; SPANNOWSKY, Willy. La mobilité urbaine. Bruxelles: Bruylant, 2010b. (Collection: Association internationale de droit de l'urbanisme).

ALVES CORREIA, Jorge. Concertação, contratação e instrumentos financeiros na reabilitação urbana. In: CEDOUA. O novo regime da reabilitação urbana. Coimbra: Almedina, 2010.

ALVES CORREIA, Jorge. Contrato e poder administrativo: o problema do contrato sobre o exercício de poderes públicos. Coimbra: Gestlegal, 2018. p. 396, 713-721 e 753-757.

ALVES CORREIA, Jorge. Contratos urbanísticos: concertação, contratação e neocontratualismo no direito do urbanismo. Coimbra: Almedina, out. 2009. p. 51 et seq.

ARNOLD, Craig Anthony. Planning Milagros: environmental justice and land use regulation. Denver University Law Review, Denver, v. 76, n. 1, 1988. p. 76.

BRENNER, Neil. Is tactical urbanism an alternative to neoliberal urbanism? Post, 24 Mar. 2015. Disponível em: https://post.at.moma.org/content_items/587-is-tactical-urbanism-an-alternative-toneoliberal-urbanism. Acesso em: 16 jul. 2020.

BRITO, Miguel Nogueira de. Direito de polícia. In: OTERO, Paulo; GONÇALVES, Pedro (coord.). Tratado de direito administrativo especial. Coimbra: Almedina, 2009. v. 1. p. 281-456. p. 317-318.

CANOTILHO, José Joaquim Gomes; MOREIRA, Vital. Constituição da República portuguesa anotada. 4. ed. Coimbra: Coimbra Editora, 2007. v. 1, p. 478-479.

CARVALHO, Jorge. Ordenar a cidade. Coimbra: Quarteto, 2003. p. 307-311.

CROWE, Timothy D. Crime prevention through environmental design. Revised by Lawrence J. Fennelly. 3. ed. Oxford: Butterworth-Heinemann, 2013. p. 3-14. 
DEMOUVEAUX, Jean-Pierre. La notion de renouvellement urbain. In: DROIT de l'aménagement de l'urbanisme et de l'habitat. 6. ed. Paris: Le Moniteur, 2002. p. 125-140. p. 127-128.

FRIAUF, Karl Heinrich. Polizei- und Ordnungsrecht. In: MÜNCH, Ingo von (org.). Besonderes Verwaltungsrecht, 7. ed. Berlin: W. de Gruyter, 1984. p. 181-254. p. 187.

GARCIA, Maria da Glória Ferreira Pinto Dias. Habitação, direito e políticas públicas. In: SOUSA, Marcelo Rebelo de; QUADROS, Fausto de; OTERO, Paulo; PINTO, Eduardo Vera-Cruz (coord.). Estudos de homenagem ao prof. doutor Jorge Miranda. Coimbra: Coimbra Editora, 2012. v. 4: direito administrativo e justiça administrativa. p. 651-667.

IMTT. Diretrizes nacionais para a mobilidade. Lisboa: IMTT, jan. 2012. p. 30 et seq. Disponível em: $\quad$ http://www.imt-ip.pt/sites/IMTT/Portugues/Planeamento/DocumentosdeReferencia/ PacotedaMobilidade/Documents/Pacote\%20da\%20Mobilidade/Directrizes_vposconsultapublica_ abril2012.pdf.

JÉGOUZO, Yves. La notion de renouvellement urbain. In: RENDERS, David et al. Le renouvellement urbain en Europe. Paris: Gridauh, 2014. p. 13-24. p. 15-16. (Les Cahiers du GRIDAUH, n. $\left.{ }^{\circ} 27\right)$.

LOPES, Dulce. Reabilitação urbana em Portugal: evolução e caracterização. In: CEDOUA. O novo regime da reabilitação urbana. Coimbra: Almedina, 2010. p. 22-25.

MIRANDA, João. A função pública urbanística e o seu exercício por particulares. Coimbra: Coimbra Editora, 2012. p. 181-185.

MORAND-DEVILLER, Jacqueline. Droit administratif: cours, thèmes de réflexion, commentaires d'arrêts avec corrigés. 14. ed. Paris: Montchrestien, 2015. p. 525 e 526.

MORAND-DEVILLER, Jacqueline. Rapport de synthèse. In: RENDERS, David et al. Le renouvellement urbain en Europe. Paris: Gridauh, 2014. p. 107-118. p. 109. (Les Cahiers du GRIDAUH, n. ${ }^{\circ}$ 27).

NABAIS, José Casalta. Algumas considerações sobre o quadro jurídico do património cultural. Boletim Municipal de Cultura, Aveiro, n. ${ }^{\circ} 37$, p. 188-192, junho de 2001.

NABAIS, José Casalta. Introdução ao direito do património cultural. 2. ed. Coimbra: Almedina, 2010.

OLIVEIRA, Fernanda Paula Marques de. Novas tendências do direito do urbanismo: de um urbanismo de expansão e de segregação a um urbanismo de contenção, de reabilitação urbana e de coesão social. Coimbra: Almedina, 2011. p. 107-121.

OLIVEIRA, Fernanda Paula Marques de. Programação e execução das operações de reabilitação urbana: perspectiva jurídica. In: CEDOUA. O novo regime da reabilitação urbana. Coimbra: Almedina, 2010. p. 93-120.

OLIVEIRA, Fernanda Paula Marques de; LOPES, Dulce; ALVES, Cláudia. Regime jurídico da reabilitação urbana: comentado. Coimbra: Almedina, 2011. 
PORTUGAL. [(Constituição (1976)]. Constituição da República Portuguesa. Diário da República, Lisboa, $1^{a}$ série, n. 86, 10 abr. 1976. Disponível em: https://dre.pt/legislacao-consolidada/-/ lc/34520775/view.

PORTUGAL. Acórdão n. ${ }^{\circ}$ 436/2000. T. Const. - Processo n. ${ }^{\circ}$ 309/95. Diário da República, Lisboa, 2a série, n. 266, p. 18.707-18.711, 17 nov. 2000. Disponível em: https://dre.pt/application/ conteudo/2867363.

PORTUGAL. Acórdão n. ${ }^{\circ}$ 471/2001. Processo n. ${ }^{\circ}$ 666/99. Diário da República, Lisboa, $2^{\mathrm{a}}$ série, n. 163, p. 12.712-12.714, 17 jul. 2002a. Disponível em: https://dre.pt/application/conteudo/3117441.

PORTUGAL. Acórdão n. ${ }^{\circ}$ 479/94. Pronuncia-se pela inconstitucionalidade das normas conjugadas dos artigos 1. ${ }^{\circ}$, n. ${ }^{\circ} 1$, e $3 .^{\circ},{ }^{\circ}{ }^{\circ} 1$, do decreto n. ${ }^{\circ}$ 161/VI da Assembleia da República. Diário da República, Lisboa, $1^{\mathrm{a}}$ série, n. 195, p. 4.907-4.931, 24 ago. 1994. Disponível em: https://dre.pt/ application/conteudo/218749.

PORTUGAL. Declaração de Retificação n. ${ }^{\circ}$ 11/2019. Declaração de retificação à Lei n. ${ }^{\circ}$ 13/2019, de 12 de fevereiro, «Medidas destinadas a corrigir situações de desequilíbrio entre arrendatários e senhorios, a reforçar a segurança e a estabilidade do arrendamento urbano e a proteger arrendatários em situação de especial fragilidade». Diário da República, Lisboa, $1^{\text {a }}$ série, n. 67, p. 1.838-1.840, 4 abr. 2019a. Disponível em: https://dre.pt/application/conteudo/121987030.

PORTUGAL. Declaração de Retificação n. ${ }^{\circ}$ 30-A/2010. Rectifica a Resolução do Conselho de Ministros n. ${ }^{\circ}$ 53/2010, de 2 de Agosto, que aprova o Plano Regional de Ordenamento do Território do Alentejo e revoga o Plano Regional de Ordenamento do Território do Alentejo Litoral, o Plano Regional de Ordenamento do Território da Zona Envolvente de Alqueva e o Plano Regional de Ordenamento do Território da Zona dos Mármores, aprovados, respectivamente, pelo Decreto Regulamentar n. ${ }^{\circ}$ 26/93, de 27 de Agosto, pela Resolução do Conselho de Ministros n. ${ }^{0}$ 70/2002, de 9 de Abril, e pela Resolução do Conselho de Ministros n. ${ }^{\circ}$ 93/2002, de 8 de Maio, publicada no Diário da República, 1. ${ }^{\text {a }}$ série, n. ${ }^{\circ}$ 148, de 2 de Agosto de 2010. Diário da República, Lisboa, $1^{a}$ série, n. 192, p. 4.372-(8)-4.372-(92), 1 out. 2010a. Disponível em: https://dre.pt/application/ conteudo/480969.

PORTUGAL. Declaração de Retificação n. ${ }^{\circ}$ 46-A/2014. Retifica o Decreto-Lei n. ${ }^{\circ}$ 136/2014, de 9 de setembro, do Ministério do Ambiente, Ordenamento do Território e Energia, que procede à décima terceira alteração ao Decreto-Lei n. ${ }^{\circ}$ 555/99, de 16 de dezembro, que estabelece o regime jurídico da urbanização e edificação, publicado no Diário da República, 1. a série, n. ${ }^{\circ} 173$, de 9 de setembro de 2014. Diário da República, Lisboa, $1^{\text {a }}$ série, n. 217, p. 5.720-(2)- 5.720-(2), 10 nov. 2014a. Disponível em: https://dre.pt/application/conteudo/58815340.

PORTUGAL. Declaração de Retificação n. ${ }^{\circ}$ 80-A/2007. Rectifica a Lei n. ${ }^{\circ}$ 58/2007 (aprova o Programa Nacional da Política de Ordenamento do Território), publicada no Diário da República, 1. ${ }^{\mathrm{a}}$ série, n. $^{\circ} 170$, de 4 de Setembro de 2007. Diário da República, Lisboa, $1^{\mathrm{a}}$ série, n. 173, p. 6.352(2)-6.352-(58), 7 set. 2007a. Disponível em: https://dre.pt/application/conteudo/683002. 
PORTUGAL. Decreto-Lei n. ${ }^{\circ}$ 1/2020. Cria o direito real de habitação duradoura. Diário da República, Lisboa, 1a série, n. 6, p. 2-1, 9 jan. 2020a. Disponível em: https://dre.pt/application/ conteudo/127899795.

PORTUGAL. Decreto-Lei n. ${ }^{\circ}$ 9/2007. Aprova o Regulamento Geral do Ruído e revoga o regime legal da poluição sonora, aprovado pelo Decreto-Lei n. ${ }^{\circ}$ 292/2000, de 14 de Novembro. Diário da República, Lisboa, $1^{\text {a }}$ série, n. 12, p. 389-398, 17 jan. 2007b. Disponível em: https://dre.pt/ application/conteudo/522807.

PORTUGAL. Decreto-Lei n. ${ }^{\circ}$ 53/2014. Estabelece um regime excecional e temporário a aplicar à reabilitação de edifícios ou de frações, cuja construção tenha sido concluída há pelo menos 30 anos ou localizados em áreas de reabilitação urbana, sempre que estejam afetos ou se destinem a ser afetos total ou predominantemente ao uso habitacional. Diário da República, Lisboa, $1^{\text {a }}$ série, n. 69 , p. 2.337-2.340, 8 abr. 2014b. https://dre.pt/application/conteudo/25344757.

PORTUGAL. Decreto-Lei n. ${ }^{\circ}$ 55/2016. Define a missão e atribuições da Agência Portuguesa do Ambiente, I. P., nos domínios do litoral, da proteção costeira, das alterações climáticas e da proteção do ar, procedendo à primeira alteração ao Decreto-Lei n. ${ }^{0}$ 56/2012, de 12 de março. Diário da República, Lisboa, $1^{\mathrm{a}}$ série, n. 164, p. 2.961-2.962, 26 ago. 2016a. Disponível em: https://dre.pt/ application/conteudo/75207498.

PORTUGAL. Decreto-Lei n. ${ }^{\circ}$ 56/2012. Aprova a orgânica da Agência Portuguesa do Ambiente, I. P. Diário da República, Lisboa, $1^{\mathrm{a}}$ série, n. 51, p. 1.093-1.098, 12 mar. 2012a. Disponível em: https:// dre.pt/application/conteudo/553603.

PORTUGAL. Decreto-Lei n. ${ }^{\circ}$ 63/2015. Procede à primeira alteração ao Decreto-Lei n. ${ }^{\circ}$ 128/2014, de 29 de agosto, que estabelece o regime jurídico da exploração dos estabelecimentos de alojamento local. Diário da República, Lisboa, $1^{\text {a }}$ série, n. 79, p. 2.048-2.049, 23 abr. 2015a. https://dre.pt/ application/conteudo/67059141.

PORTUGAL. Decreto-Lei n. ${ }^{\circ}$ 66/2019. Altera as regras aplicáveis à intimação para a execução de obras de manutenção, reabilitação ou demolição e sua execução coerciva. Diário da República, Lisboa, $1^{a}$ série, n. 97, p. 2.526-2.530, 21 maio 2019b. Disponível em: https://dre.pt/application/ conteudo/122349220.

PORTUGAL. Decreto-Lei n. ${ }^{\circ}$ 67/2019. Procede ao agravamento do imposto municipal sobre imóveis relativamente a prédios devolutos em zonas de pressão urbanística. Diário da República, Lisboa, $1^{a}$ série, n. 97, p. 2.530-2.537, 21 maio 2019c. Disponível em: https://dre.pt/application/ conteudo/122349221.

PORTUGAL. Decreto-Lei n. ${ }^{\circ}$ 68/2019. Cria o Programa de Arrendamento Acessível. Diário da República, Lisboa, $1^{\mathrm{a}}$ série, n. 98, p. 2.546-2.553, 22 maio 2019d. Disponível em: https://dre.pt/ application/conteudo/122373682.

PORTUGAL. Decreto-Lei n. ${ }^{\circ}$ 69/2019. Estabelece o regime especial dos contratos de seguro de arrendamento acessível no âmbito do Programa de Arrendamento Acessível. Diário da República, 
Lisboa, $1^{a}$ série, n. 98, p. 2.553-2.557, 22 maio 2019e. Disponível em: https://dre.pt/application/ conteudo/122373683.

PORTUGAL. Decreto-Lei n. ${ }^{\circ}$ 79/2017. Protege o património azulejar, procedendo à décima terceira alteração ao Regime Jurídico da Urbanização e Edificação, aprovado pelo Decreto-Lei n. ${ }^{0}$ 555/99, de 16 de dezembro. Diário da República, Lisboa, 1ª série, n. 159, p. 4.781-4.781, 18 ago. 2017a. Disponível em: https://dre.pt/application/conteudo/108016474.

PORTUGAL. Decreto-Lei n. ${ }^{\circ}$ 80/2015. Regime Jurídico dos Instrumentos de Gestão Territorial. Diário da República, Lisboa, $1^{\text {a }}$ série, n. 93, 14 maio 2015b. Disponível em: https://dre.pt/legislacaoconsolidada/-/lc/105297982/view?p_p_state=maximized.

PORTUGAL. Decreto-Lei n. ${ }^{\circ}$ 88/2017. Altera o regime das sociedades de reabilitação urbana. Diário da República, Lisboa, $1^{\mathrm{a}}$ série, n. 144, p. 4.259-4.260, 27 jul. 2017b. Disponível em: https:// dre.pt/application/conteudo/107761915.

PORTUGAL. Decreto-Lei n. ${ }^{\circ}$ 94/2019. Aprova o plano de reabilitação de património público para arrendamento acessível. Diário da República, Lisboa, $1^{a}$ série, n. 134, p. 2-1, 16 jul. 2019f. Disponível em: https://dre.pt/application/conteudo/123183036.

PORTUGAL. Decreto-Lei n. ${ }^{\circ}$ 97/2017. Estabelece o regime das instalações de gases combustíveis em edifícios. Diário da República, Lisboa, $1^{\text {a }}$ série, n. 154, p. 4.663-4.672, 10 ago. 2017c. Disponível em: https://dre.pt/application/conteudo/107987278.

PORTUGAL. Decreto-Lei n. ${ }^{\circ}$ 105/2018. Concretiza o quadro de transferência de competências para os órgãos municipais no domínio da habitação. Diário da República, Lisboa, $1^{a}$ série, n. 230, p. 5.440-5.444, 29 nov. 2018a. Disponível em: https://dre.pt/application/conteudo/117142871.

PORTUGAL. Decreto-Lei n. ${ }^{\circ}$ 108/2018. Estabelece o regime jurídico da proteção radiológica, transpondo a Diretiva 2013/59/Euratom. Diário da República, Lisboa, $1^{a}$ série, n. 232, p. 5.4905.543, 3 dez. 2018b. Disponível em: https://dre.pt/application/conteudo/117202785.

PORTUGAL. Decreto-Lei n. ${ }^{\circ}$ 121/2018. Altera o Regime Jurídico da Urbanização e Edificação. Diário da República, Lisboa, $1^{\mathrm{a}}$ série, n. 250, p. 5.959-5.959, 28 dez. 2018c. Disponível em: https:// dre.pt/application/conteudo/117514512.

PORTUGAL. Decreto-Lei n. ${ }^{\circ}$ 128/2014. Aprova o regime jurídico da exploração dos estabelecimentos de alojamento local. Diário da República, Lisboa, $1^{\mathrm{a}}$ série, n. 166, p. 4.570-4.577, 29 ago. 2014c. https://dre.pt/application/conteudo/56384880.

PORTUGAL. Decreto-Lei n. ${ }^{\circ}$ 136/2014. Procede à décima terceira alteração ao Decreto-Lei n. ${ }^{\circ}$ 555/99, de 16 de dezembro, que estabelece o regime jurídico da urbanização e edificação. Diário da República, Lisboa, $1^{\text {a }}$ série, n. 173, p. 4.809-4.860, 9 set. 2014d. Disponível em: https://dre.pt/ application/conteudo/56501680.

PORTUGAL. Decreto-Lei n. ${ }^{\circ}$ 151-B/2013. Estabelece o regime jurídico da avaliação de impacte ambiental (AIA) dos projetos públicos e privados suscetíveis de produzirem efeitos significativos 
no ambiente, transpondo a Diretiva n. ${ }^{\circ}$ 2011/92/UE, do Parlamento Europeu e do Conselho, de 13 de dezembro, relativa à avaliação dos efeitos de determinados projetos públicos e privados no ambiente. Diário da República, Lisboa, 1ª série, n. 211, p. 6.328-(6)-6.328(31), 31 out. 2013a. Disponível em: https://dre.pt/application/conteudo/513863.

PORTUGAL. Decreto-Lei n. ${ }^{\circ}$ 152-B/2017. Altera o regime jurídico da avaliação de impacte ambiental dos projetos públicos e privados suscetíveis de produzirem efeitos significativos no ambiente, transpondo a Diretiva n. ${ }^{\circ}$ 2014/52/EU. Diário da República, Lisboa, $1^{\text {a }}$ série, n. 236, p. 6.584-(12)6.584-(52), 11 set. 2017d. Disponível em: https://dre.pt/application/conteudo/114337013.

PORTUGAL. Decreto-Lei n. ${ }^{\circ}$ 159/2012. Regula a elaboração e a implementação dos planos de ordenamento da orla costeira e estabelece o regime sancionatório aplicável às infrações praticadas na orla costeira, no que respeita ao acesso, circulação e permanência indevidos em zonas interditas e respetiva sinalização. Diário da República, Lisboa, 1ª série, n. 142, p. 3.881-3.890, 24 jul. 2012 b. Disponível em: https://dre.pt/application/conteudo/179368.

PORTUGAL. Decreto-Lei n. ${ }^{\circ}$ 179/2015. Procede à segunda alteração ao Decreto-Lei n. ${ }^{\circ}$ 151B/2013, de 31 de outubro, que estabelece o regime jurídico da avaliação de impacte ambiental dos projetos públicos e privados suscetíveis de produzirem efeitos significativos no ambiente, transpondo para a ordem jurídica interna a Diretiva n. ${ }^{\circ}$ 2011/92/UE, do Parlamento Europeu e do Conselho, de 13 de dezembro de 2011, relativa à avaliação dos efeitos de determinados projetos públicos e privados no ambiente. Diário da República, Lisboa, $1^{\text {a }}$ série, n. 167, p. 6.429-6.434, 27 ago. 2015c. Disponível em: https://dre.pt/application/conteudo/70128402.

PORTUGAL. Decreto-Lei n. ${ }^{\circ}$ 194/2015. Procede à segunda alteração ao Decreto-Lei n. ${ }^{\circ}$ 118/2013, de 20 de agosto, relativo ao desempenho energético dos edifícios, e à primeira alteração ao DecretoLei n. ${ }^{\circ}$ 53/2014, de 8 de abril, que estabelece um regime excecional e temporário aplicável à reabilitação de edifícios ou de frações, cuja construção tenha sido concluída há pelo menos 30 anos ou localizados em áreas de reabilitação urbana, sempre que se destinem a ser afetos total ou predominantemente ao uso habitacional. Diário da República, Lisboa, $1^{\text {a }}$ série, n. 179, p. 7.8997.922, 14 set. 2015d. https://dre.pt/application/conteudo/70280719.

PORTUGAL. Decreto-Lei n. ${ }^{\circ}$ 214-G/2015. No uso da autorização legislativa concedida pela Lei n. ${ }^{\circ}$ 100/2015, de 19 de agosto, revê o Código de Processo nos Tribunais Administrativos, o Estatuto dos Tribunais Administrativos e Fiscais, o Código dos Contratos Públicos, o Regime Jurídico da Urbanização e da Edificação, a Lei de Participação Procedimental e de Ação Popular, o Regime Jurídico da Tutela Administrativa, a Lei de Acesso aos Documentos Administrativos e a Lei de Acesso à Informação sobre Ambiente. Diário da República, Lisboa, $1^{\text {a }}$ série, n. 193, p. 8.588(12)8.588(108), 2 out. 2015e. Disponível em: https://dre.pt/application/conteudo/70423756.

PORTUGAL. Decreto-Lei n. ${ }^{\circ}$ 278/2007. Altera o Decreto-Lei n. ${ }^{\circ}$ 9/2007, de 17 de Janeiro, que aprova o Regulamento Geral do Ruído. Diário da República, Lisboa, $1^{\text {a }}$ série, n. 147, p. 4.9124.913, 1 ago. 2007c. Disponível em: https://dre.pt/application/conteudo/636389. 
PORTUGAL. Decreto-Lei n. ${ }^{\circ}$ 307/2009. No uso da autorização concedida pela Lei n. ${ }^{\circ}$ 95A/2009, de 2 de Setembro, aprova o regime jurídico da reabilitação urbana. Diário da República, Lisboa, $1^{a}$ série, n. 206, p. 7.956-7.975, 23 out. 2009. Disponível em: https://dre.pt/application/ conteudo/483155.

PORTUGAL. Decreto-Lei n. ${ }^{0}$ 555/99. Estabelece o regime jurídico da urbanização e edificação. Diário da República, Lisboa, $1^{\text {a }}$ série, n. 291, p. 8.912-8.942, 16 dez. 1999. Disponível em: https:// dre.pt/application/conteudo/655682.

PORTUGAL. Decreto-Lei n. ${ }^{\circ}$ 47.344/1966. Aprova o Código Civil e regula a sua aplicação Revoga, a partir da data da entrada em vigor do novo Código Civil, toda a legislação civil relativa às matérias que o mesmo abrange. Diário da República, Lisboa, $1^{\mathrm{a}}$ série, n. 274, p. 1.883-2.086, 25 nov. 1966. Disponível em: https://dre.pt/application/conteudo/477358.

PORTUGAL. Lei n. ${ }^{\circ}$ 2/2020. Orçamento do Estado para 2020. Diário da República, Lisboa, $1^{\mathrm{a}}$ série, n. 64, p. 2-336, 31 mar. 2020b. Disponível em: https://dre.pt/application/conteudo/130893436.

PORTUGAL. Lei n. ${ }^{\circ}$ 6/2006. Aprova o Novo Regime do Arrendamento Urbano (NRAU), que estabelece um regime especial de actualização das rendas antigas, e altera o Código Civil, o Código de Processo Civil, o Decreto-Lei n. ${ }^{\circ}$ 287/2003, de 12 de Novembro, o Código do Imposto Municipal sobre Imóveis e o Código do Registo Predial. Diário da República, Lisboa, $1^{\text {a }}$ série, n. 41, p. 1.5581.587, 27 fev. 2006. Disponível em: https://dre.pt/application/conteudo/693853.

PORTUGAL. Lei n. ${ }^{\circ}$ 10/2019. Cria o Observatório da Habitação, do Arrendamento e da Reabilitação Urbana para acompanhamento do mercado de arrendamento urbano nacional. Diário da República, Lisboa, $1^{\text {a }}$ série, n. 27, p. 990-990, 7 fev. 2019g. Disponível em: https://dre.pt/application/ conteudo/119236546.

PORTUGAL. Lei n. ${ }^{\circ}$ 12/2019. Proíbe e pune o assédio no arrendamento, procedendo à quinta alteração ao Novo Regime do Arrendamento Urbano, aprovado pela Lei n. ${ }^{\circ}$ 6/2006, de 27 de fevereiro. Diário da República, Lisboa, 1a série, n. 30, p. 1.172-1.172, 12 fev. 2019h. Disponível em: https://dre.pt/application/conteudo/119397714.

PORTUGAL. Lei n. ${ }^{0}$ 13/2019. Medidas destinadas a corrigir situações de desequilíbrio entre arrendatários e senhorios, a reforçar a segurança e a estabilidade do arrendamento urbano e a proteger arrendatários em situação de especial fragilidade. Diário da República, Lisboa, $1^{\mathrm{a}}$ série, n. 30, p. 1.173-1.181, 12 fev. 2019i. Disponível em: https://dre.pt/application/conteudo/119397715.

PORTUGAL. Lei n. ${ }^{\circ}$ 19/2014. Define as bases da política de ambiente. Diário da República, Lisboa, $1^{a}$ série, n. 73, p. 2.400-2.404, 14 abr. 2014e. Disponível em: https://dre.pt/application/ conteudo/25344037.

PORTUGAL. Lei n. ${ }^{\circ}$ 32/2012. Procede à primeira alteração ao Decreto-Lei n. ${ }^{\circ}$ 307/2009, de 23 de outubro, que estabelece o regime jurídico da reabilitação urbana, e à 54. ${ }^{a}$ alteração ao Código Civil, aprovando medidas destinadas a agilizar e a dinamizar a reabilitação urbana. Diário da República, 
Lisboa, $1^{a}$ série, n. 157, p. 4.452-4.483, 14 ago. 2012c. Disponível em: https://dre.pt/application/ conteudo/175306.

PORTUGAL. Lei n. ${ }^{0}$ 37/2017. Estabelece as regras aplicáveis à disponibilização no mercado de recipientes sob pressão simples, transpondo a Diretiva n. ${ }^{\circ}$ 2014/29/UE. Diário da República, Lisboa, $1^{a}$ série, n. 63, p. 1.644-1.662, 29 mar. 2017e. Disponível em: https://dre.pt/application/ conteudo/106663844.

PORTUGAL. Lei n. ${ }^{\circ}$ 43/2019. Procede à interpretação autêntica do n. ${ }^{\circ} 7$ do artigo $1.041 .^{\circ}$ do Código Civil, aditado pelo artigo $2 .^{\circ}$ da Lei n. ${ }^{\circ} 13 / 2019$, de 12 de fevereiro, que estabelece medidas destinadas a corrigir situações de desequilíbrio entre arrendatários e senhorios, a reforçar a segurança e a estabilidade do arrendamento urbano e a proteger arrendatários em situação de especial fragilidade. Diário da República, Lisboa, $1^{\text {a }}$ série, n. 117, p. 3.012-3.012, 21 jun. 2019j. Disponível em: https://dre.pt/application/conteudo/122627508.

PORTUGAL. Lei n. ${ }^{\circ}$ 47/2014. Procede à primeira alteração ao Decreto-Lei n. ${ }^{\circ}$ 151-B/2013, de 31 de outubro, que estabelece o regime jurídico de avaliação de impacte ambiental (AIA) dos projetos públicos e privados suscetíveis de produzirem efeitos significativos no ambiente, transpondo a Diretiva n. ${ }^{\circ}$ 2011/92/UE, do Parlamento Europeu e do Conselho, de 13 de dezembro de 2011, relativa à avaliação dos efeitos de determinados projetos públicos e privados no ambiente. Diário da República, Lisboa, $1^{\mathrm{a}}$ série, n. 58, p. 2.161-2.163, 24 mar. 2014f. Disponível em: https://dre.pt/ application/conteudo/572123.

PORTUGAL. Lei n. ${ }^{\circ}$ 50/2018. Lei-quadro da transferência de competências para as autarquias locais e para as entidades intermunicipais. Diário da República, Lisboa, $1^{\mathrm{a}}$ série, n. 157, p. 4.1024.108, 16 ago. 2018d. Disponível em: https://dre.pt/application/conteudo/116068877.

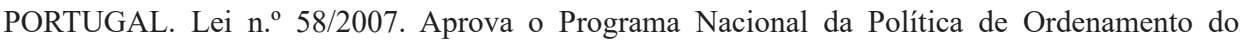
Território. Diário da República, Lisboa, $1^{\text {a }}$ série, n. 170, p. 6.126-6.181, 4 set. 2007d. Disponível em: https://dre.pt/application/conteudo/640143.

PORTUGAL. Lei n. ${ }^{\circ}$ 62/2018. Altera o regime de autorização de exploração dos estabelecimentos de alojamento local, procedendo à segunda alteração ao Decreto-Lei n. ${ }^{\circ}$ 128/2014, de 29 de agosto. Diário da República, Lisboa, $1^{\mathrm{a}}$ série, n. 161, p. 4.300-4.312, 22 ago. 2018e. Disponível em: https:// dre.pt/application/conteudo/116152179.

PORTUGAL. Lei n. ${ }^{\circ}$ 72/2013. Décima terceira alteração ao Código da Estrada, aprovado pelo Decreto-Lei n. ${ }^{0}$ 114/94, de 3 de maio, e primeira alteração ao Decreto-Lei n. ${ }^{o}$ 44/2005, de 23 de fevereiro. Diário da República, Lisboa, $1^{\text {a }}$ série, n. 169, p. 5.446-5.499, 3 set. 2013b. Disponível em: https://dre.pt/application/conteudo/499526.

PORTUGAL. Lei n. ${ }^{o}$ 83/2019. Lei de bases da habitação. Diário da República, Lisboa, $1^{\mathrm{a}}$ série, n. 168, p. 11-33, 3 set. 2019k. Disponível em: https://dre.pt/application/conteudo/124392055. 
PORTUGAL. Lei n. ${ }^{\circ}$ 99/2019. Primeira revisão do Programa Nacional da Política do Ordenamento do Território (revoga a Lei n. ${ }^{\circ}$ 58/2007, de 4 de setembro). Diário da República, Lisboa, $1^{\text {a }}$ série, n. 170, p. 3-267, 5 set. 20191. Disponível em: https://dre.pt/application/conteudo/124457181.

PORTUGAL. Lei n. ${ }^{\circ}$ 118/2019. Modifica regimes processuais no âmbito da jurisdição administrativa e tributária, procedendo a diversas alterações legislativas. Diário da República, Lisboa, $1^{\mathrm{a}}$ série, n. 178, p. 3-198, 17 set. 2019m. Disponível em: https://dre.pt/application/conteudo/124750731.

PORTUGAL. Ministério do Ambiente, do Ordenamento do Território e do Desenvolvimento Regional. GIZC: bases para estratégia de gestão integrada da zona costeira nacional. Lisboa: Maiadouro, 2007e. p. 35. Disponível em: https://discomap.eea.europa.eu/map/Data/Milieu/ OURCOAST_126_PT/OURCOAST_126_PT_Doc1_NationalCoastManagementBasis.pdf.

PORTUGAL. Portaria n. ${ }^{\circ}$ 175/2019. Regulamenta as disposições do Decreto-Lei n. ${ }^{\circ}$ 68/2019, de 22 de maio, relativas ao registo de candidatura ao Programa de Arrendamento Acessível. Diário da República, Lisboa, $1^{a}$ série, n. 109, p. 2.902-2.904, 6 jun. 2019n. Disponível em: https://dre.pt/ application/conteudo/122520772.

PORTUGAL. Portaria n. ${ }^{\circ}$ 176/2019. Regulamenta as disposições do Decreto-Lei n. ${ }^{\circ}$ 68/2019, de 22 de maio, relativas aos limites de renda aplicáveis no âmbito do Programa de Arrendamento Acessível. Diário da República, Lisboa, 1ª série, n. 109, p. 2.904-2.907, 6 jun. 2019o. Disponível em: https://dre.pt/application/conteudo/122520773.

PORTUGAL. Portaria n. ${ }^{\circ}$ 177/2019. Regulamenta as disposições do Decreto-Lei n. ${ }^{\circ}$ 68/2019, de 22 de maio, relativas à inscrição de alojamentos no Programa de Arrendamento Acessível. Diário da República, Lisboa, $1^{\text {a }}$ série, n. 109, p. 2.907-2.908, 6 jun. 2019p. Disponível em: https://dre.pt/ application/conteudo/122520774.

PORTUGAL. Resolução do Conselho de Ministros n. ${ }^{\circ}$ 33/2013. Define os Pressupostos do Acordo de Parceria a negociar entre o Estado Português e a Comissão Europeia, estabelecendo as principais linhas de intervenção dos fundos europeus estruturais e de investimento no ciclo 2014-2020. Diário da República, Lisboa, $1^{\text {a }}$ série, n. 96, p. 2.972-2.991, 20 maio 2013c. Disponível em: https://dre.pt/ application/conteudo/260965.

PORTUGAL. Resolução do Conselho de Ministros n. ${ }^{\circ}$ 39/2013. Estabelece um novo modelo institucional de governação dos fundos europeus. Diário da República, Lisboa, $1^{\mathrm{a}}$ série, n. 113, p. 3.300-3.301, 14 jun. 2013d. Disponível em: https://dre.pt/application/conteudo/496730.

PORTUGAL. Resolução do Conselho de Ministros n. ${ }^{\circ}$ 45/2011. Aprova o Plano Estratégico dos Transportes para o horizonte 2011-2015. Diário da República, Lisboa, 1a série, n. 216, p. 4.7964.821, 10 nov. 2011. Disponível em: https://dre.pt/application/conteudo/146536.

PORTUGAL. Resolução do Conselho de Ministros n. ${ }^{\circ}$ 48/2016. Determina a criação do Fundo Nacional de Reabilitação do Edificado. Diário da República, Lisboa, $1^{a}$ série, n. 168, p. 3.110-3.111, 1 set. 2016b. Disponível em: https://dre.pt/application/conteudo/75239710. 
PORTUGAL. Resolução do Conselho de Ministros n. ${ }^{\circ}$ 50-A/2018. Aprova o sentido estratégico, objetivos e instrumentos de atuação para uma Nova Geração de Políticas de Habitação. Diário da República, Lisboa, $1^{\mathrm{a}}$ série, n. 84, p. 1.784-(2)-1.784-(2), 2 maio 2018f. Disponível em: https://dre. $\mathrm{pt} /$ application/conteudo/115211109.

PORTUGAL. Resolução do Conselho de Ministros n. ${ }^{\circ}$ 52-A/2020. Determina a fixação de prazos para a conclusão dos procedimentos referentes ao programa de regularização extraordinária dos vínculos precários na Administração Pública. Diário da República, Lisboa, $1^{\mathrm{a}}$ série, n. 126, p. 11-12, 1 jul. 2020c. Disponível em: https://dre.pt/application/conteudo/136990469.

PORTUGAL. Resolução do Conselho de Ministros n. ${ }^{\circ}$ 53/2020. Aprova o Plano Regional de Ordenamento do Território do Alentejo e revoga os Planos Regionais de Ordenamento do Território do Alentejo Litoral, da Zona Envolvente de Alqueva e da Zona dos Mármores, aprovados, respectivamente, pelo Decreto Regulamentar n. ${ }^{\circ}$ 26/93, de 27 de Agosto, e pelas Resoluções do Conselho de Ministros n.os 70/2002, de 9 de Abril, e 93/2002, de 8 de Maio. Diário da República, Lisboa, $1^{\text {a }}$ série, n. 148, p. 2.962-3.129, 2 ago. 2010b. Disponível em: https://dre.pt/application/ conteudo/333798.

PORTUGAL. Resolução do Conselho de Ministros n. ${ }^{\circ}$ 61-A/2015. Aprova a versão final revista do Plano Estratégico dos Transportes e Infraestruturas - PETI3+, para o horizonte 2014-2020. Diário da República, Lisboa, $1^{\text {a }}$ série, n. 162, p. 6.222-(2)-6.222-(1.049), 20 ago. 2015f. Disponível em: https://dre.pt/application/conteudo/70064710.

PORTUGAL. Resolução do Conselho de Ministros n. ${ }^{\circ}$ 66/2019. Aprova o Programa da Orla Costeira de Alcobaça-Cabo Espichel. Diário da República, Lisboa, $1^{a}$ série, n. 72, p. 1.950-2.065, 11 abr. 2019q. Disponível em: https://dre.pt/application/conteudo/122074192.

PORTUGAL. Resolução do Conselho de Ministros n. ${ }^{\circ}$ 68/2002. Aprova o Plano Regional de Ordenamento do Território da Área Metropolitana de Lisboa (PROTAML). Diário da República, Lisboa, $1^{a}$ série, n. 82 , p. 3.287-3.328, 8 abr. 2002b. Disponível em: https://dre.pt/application/ conteudo/302557.

SILVA, Suzana Tavares da. Da "Contemplação da Ruína" ao Património sustentável: contributo para uma compreensão adequada dos bens culturais. Revista CEDOUA, Coimbra, ano 5, n. ${ }^{\circ} 10$, p. 69-93, 2002. p. 80 e 81. 